In cooperation with the U.S. Air Force

Polychlorinated Biphenyls in Aquatic Invertebrates and Fish and Observations about Nitrogen and Carbon Isotope Composition in Relation to Trophic Structure and Bioaccumulation Patterns, Lake Worth and Meandering Road Creek, Fort Worth, Texas, 2007-08

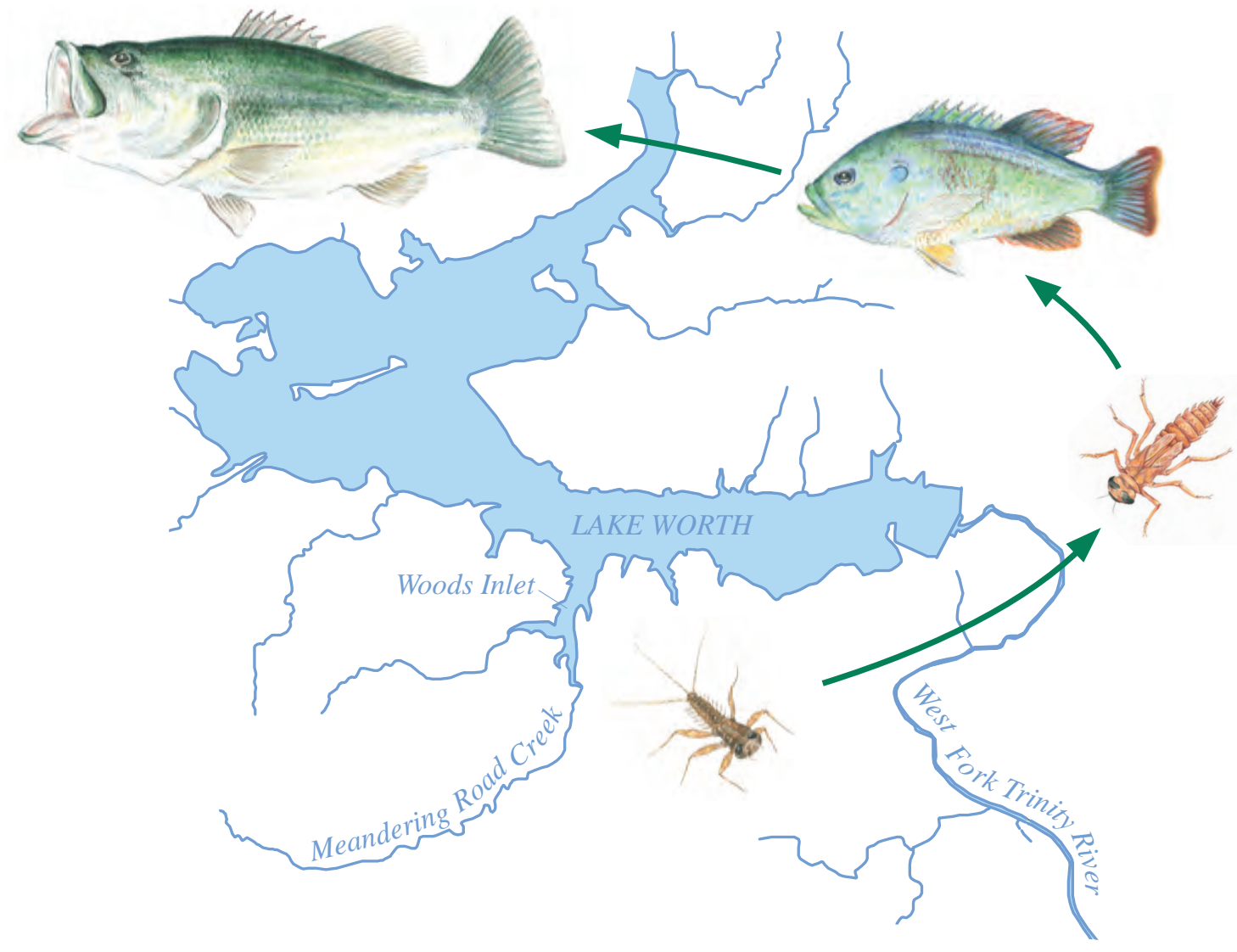

Scientific Investigations Report 2010-5235 
Front cover: Freshwater food chain showing examples of the types of organisms collected in Lake Worth or Meandering Road Creek, Fort Worth, Texas, 2007-08 (drawings by L.S. Coplin, U.S. Geological Survey). 


\section{Polychlorinated Biphenyls in Aquatic}

Invertebrates and Fish and Observations about Nitrogen and Carbon Isotope Composition in Relation to Trophic Structure and Bioaccumulation Patterns, Lake Worth and Meandering Road Creek, Fort Worth, Texas, 2007-08

By J. Bruce Moring

In cooperation with the U.S. Air Force

Scientific Investigations Report 2010-5235 


\section{U.S. Department of the Interior \\ KEN SALAZAR, Secretary \\ U.S. Geological Survey \\ Marcia K. McNutt, Director}

U.S. Geological Survey, Reston, Virginia: 2010

This and other USGS information products are available at http://store.usgs.gov/
U.S. Geological Survey
Box 25286 , Denver Federal Center
Denver, CO 80225
To learn about the USGS and its information products visit http://www.usgs.gov/
1-888-ASK-USGS

Any use of trade, product, or firm names is for descriptive purposes only and does not imply endorsement by the U.S. Government.

Although this report is in the public domain, permission must be secured from the individual copyright owners to reproduce any copyrighted materials contained within this report.

Suggested citation:

Moring, J.B., 2010, Polychlorinated biphenyls in aquatic invertebrates and fish and observations about nitrogen and carbon isotope composition in relation to trophic structure and bioaccumulation patterns, Lake Worth and Meandering Road Creek, Fort Worth, Texas, 2007-08: U.S. Geological Survey Scientific Investigations Report 2010-5235, 29 p. 


\section{Contents}

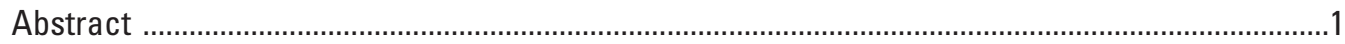

Introduction

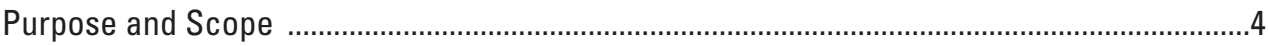

Description of Study Area .......................................................................................................

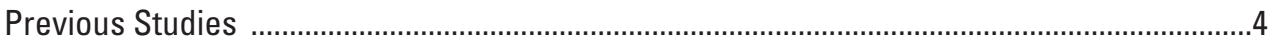

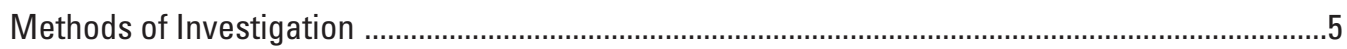

Collection and Processing of Samples .....................................................................................

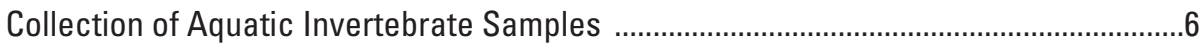

Collection of Fish Samples ................................................................................................

Processing of Aquatic Invertebrate and Fish Samples ....................................................7

Analysis of Polychlorinated Biphenyl Congeners ...................................................................

Analysis of Stable Nitrogen and Carbon Isotopes ...............................................................

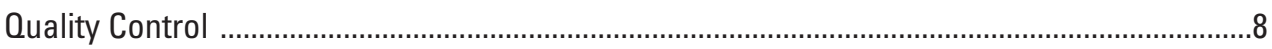

Polychlorinated Biphenyls in Aquatic Invertebrates and Fish ........................................................10

Observations about Nitrogen and Carbon Isotope Composition in Relation to Trophic

Structure and Bioaccumulation Patterns ..........................................................................12

Trophic Levels and Stable Isotope Composition ........................................................................12

Horizontal Food Web Position and Stable Isotope Composition ..............................................12

Enrichment of Nitrogen-15 and Trophic Structure of Aquatic Invertebrates and Fish ..........13

Nitrogen Isotope Enrichment and Polychlorinated Biphenyl Concentrations in Aquatic Invertebrates and Fish ................................................................................................ 15

Implications for Ecological Processes and Polychlorinated Biphenyl Concentrations in

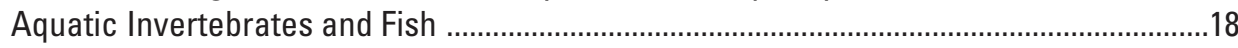

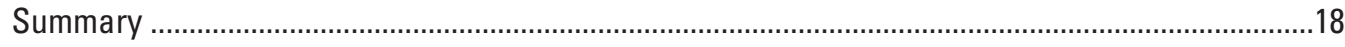

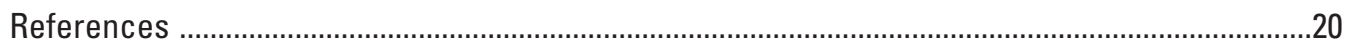

Appendixes

1. Relative percent difference for duplicate polychlorinated biphenyl congener and isotope data for aquatic invertebrate and fish samples collected in Lake Worth, Woods Inlet, and Meandering Road Creek, Fort Worth, Texas, 2007-08

2. Laboratory sample blank and spike percent recovery for polychlorinated biphenyl congeners and surrogate compounds for two sets analyzed concurrently with aquatic invertebrate and fish samples collected in Lake Worth, Woods Inlet, and Meandering Road Creek, Fort Worth, Texas, 2007-08

3. Concentrations of selected polychlorinated biphenyl congeners and number of chlorinated substitutes for aquatic invertebrate and fish composite samples collected in Lake Worth, Woods Inlet, and Meandering Road Creek, Fort Worth, Texas, 2007-08

\section{Figures}

1. Map showing location of study area and approximate sampling locations for aquatic invertebrates and fish in Lake Worth, Woods Inlet, and Meandering Road Creek, Fort Worth, Texas, 2007-08 


\section{2-6. Graphs showing:}

2. Relation between sum of 15 polychlorinated biphenyl congeners $\left(\sum \mathrm{PCB}_{\mathrm{C} 15}\right)$ in surficial (top 5 centimeters) bed-sediment samples (Braun and others, 2008) collected in Lake Worth, Woods Inlet, and Meandering Road Creek, 2006 , and $\sum \mathrm{PCB}_{\mathrm{C15}}$ in aquatic invertebrate and fish samples collected in approximately the same locations, 2007-08, Fort Worth, Texas

3. Relation between delta nitrogen-15 $\left(\delta^{15} \mathrm{~N}\right)$ and delta carbon- $13\left(\delta^{13} \mathrm{C}\right)$ in aquatic invertebrate and fish composite samples collected in Lake Worth, Woods Inlet, and Meandering Road Creek, Fort Worth Texas, 2007-08

4. Sum of 15 polychlorinated biphenyl congeners $\left(\sum \mathrm{PCB}_{\mathrm{c} 15}\right)$ compared with amount of nitrogen enrichment (represented by an increase in ratio of nitrogen-15 to nitrogen-14 [ $\left.\delta^{15} \mathrm{~N}\right]$ ) in aquatic invertebrate and fish composite samples collected at reference site Lake Worth near State Highway 199 Bridge (004LW), Fort Worth, Texas, 2007-08

5. Sum of 15 polychlorinated biphenyl congeners $\left(\sum P C B_{C 15}\right)$ compared with amount of nitrogen enrichment (represented by an increase in ratio of nitrogen- 15 to nitrogen-14 [ $\left.\delta^{15} \mathrm{~N}\right]$ ) in aquatic invertebrate and fish composite samples collected at Lake Worth in upper and lower Woods Inlet (sites 002WI and 003WI), Fort Worth, Texas, 2007-08

6. Sum of 15 polychlorinated biphenyl congeners $\left(\sum P C B_{C 15}\right)$ compared with amount of nitrogen enrichment (represented by an increase in ratio of nitrogen- 15 to nitrogen-14 [ $\left.\delta^{15} \mathrm{~N}\right]$ ) in aquatic invertebrate and fish composite samples collected at Meandering Road Creek (site 001MC), Fort Worth, Texas, 2007-08

\section{Tables}

1. Description of sampling sites and sample size of aquatic invertebrate and fish taxa collected in Lake Worth, Woods Inlet, and Meandering Road Creek, Fort Worth, Texas, 2007-08

2. Sum of 15 polychlorinated biphenyl congeners in aquatic invertebrate and fish composite samples collected in Lake Worth, Woods Inlet, and Meandering Road Creek, Fort Worth, Texas, 2007-08

3. Nitrogen and carbon isotope enrichment in and assigned trophic level for aquatic invertebrate and fish composite samples collected in Lake Worth, Woods Inlet, and Meandering Road Creek, Fort Worth, Texas, 2007-08 


\section{Conversion Factors and Explanation of Isotope Units}

\section{SI to Inch/Pound}

\begin{tabular}{lll}
\hline \multicolumn{1}{c}{ Multiply } & By & \multicolumn{1}{c}{ To obtain } \\
\hline centimeter $(\mathrm{cm})$ & Length & inch (in.) \\
millimeter $(\mathrm{mm})$ & 0.3937 & inch (in.) \\
meter $(\mathrm{m})$ & 0.03937 & foot (ft) \\
kilometer $(\mathrm{km})$ & 3.281 & mile (mi) \\
\hline square kilometer $\left(\mathrm{km}^{2}\right)$ & 0.6214 & square mile $\left(\mathrm{mi}^{2}\right)$ \\
\hline & Area & \\
\hline cubic meter $\left(\mathrm{m}^{3}\right)$ & 0.3861 & cubic foot $\left(\mathrm{ft}^{3}\right)$ \\
\hline & Volume & \\
\hline gram $(\mathrm{g})$ & 35.31 & ounce avoirdupois $(\mathrm{oz})$ \\
\hline
\end{tabular}

Temperature in degrees Celsius $\left({ }^{\circ} \mathrm{C}\right)$ may be converted to degrees Fahrenheit $\left({ }^{\circ} \mathrm{F}\right)$ as follows:

$$
{ }^{\circ} \mathrm{F}=\left(1.8 x^{\circ} \mathrm{C}\right)+32
$$

Concentrations of polychlorinated biphenyls are given in micrograms per kilogram $(\mu \mathrm{g} / \mathrm{kg})$.

\section{Explanation of Isotope Units}

Per mil: A unit expressing the ratio of stable-isotope abundances of an element in a sample to those of a standard material. Per mil units are equivalent to parts per thousand. Stable-isotope ratios, also known as delta values, are computed as follows:

$$
\delta \text { Xsample }=\{(\text { Rsample }- \text { Rstandard }) / \text { Rstandard }\} \times 1,000,
$$

where

$\delta=$ delta,

$\mathrm{X}=$ heavier stable isotope (for example, carbon-13), and

$\mathrm{R}=$ ratio of rare (heavier) isotope to common (lighter) isotope in sample or standard.

The $\delta$ values for stable-isotope ratios discussed in this report are referenced to the following standard materials:

\begin{tabular}{lll}
\hline Element & \multicolumn{1}{c}{ R } & \multicolumn{1}{c}{ Standard } \\
\hline Nitrogen & Nitrogen-15/nitrogen-14 & Nitrogen in air \\
Carbon & Carbon-13/carbon-12 & Vienna Pee Dee Belemnite (Hut, 1987) \\
\hline
\end{tabular}


Blank Page 


\title{
Polychlorinated Biphenyls in Aquatic Invertebrates and Fish and Observations about Nitrogen and Carbon Isotope Composition in Relation to Trophic Structure and Bioaccumulation Patterns, Lake Worth and Meandering Road Creek, Fort Worth, Texas, 2007-08
}

\author{
By J. Bruce Moring
}

\section{Abstract}

During 2007-08 the U.S. Geological Survey, in cooperation with the U.S. Air Force, evaluated the concentration of polychlorinated biphenyls (PCBs) in aquatic invertebrates and fish from one site in the main body of Lake Worth, two sites in a small inlet in Lake Worth (upper and lower Woods Inlet), and one site in Meandering Road Creek in Fort Worth, Texas. The four sites sampled during 2007-08 were located at or near sites where surficial bed-sediment samples had been collected and analyzed for PCBs during previous U.S. Geological Survey studies so that PCB concentrations in aquatic invertebrates and fish and PCB concentrations in surficial bed-sediment samples could be compared. Stable nitrogen and carbon isotopes were used to help assess differences in the amount of these isotopes by species and sampling location. The sum of 15 PCB-congener concentrations was highest for aquatic invertebrates and fish from the upper Woods Inlet site and lowest for the same aquatic invertebrates and fish from the Lake Worth site, where PCBs historically had not been detected in lake bed sediment. An increase in the ratio of the heavier nitrogen- $15\left({ }^{15} \mathrm{~N}\right)$ isotope to the lighter nitrogen-14 $\left({ }^{14} \mathrm{~N}\right)$ isotope, referred to as enrichment of ${ }^{15} \mathrm{~N}$, was highest in largemouth bass (representing the highest trophic level sampled) at all sites and lowest for true midge larvae inhabiting surficial bed sediment in the lake (representing the lowest trophic level sampled). Enrichment of ${ }^{15} \mathrm{~N}$ was less variable in largemouth bass and other fish from the highest trophic level compared with shorter lived, primary consumer invertebrates from lower trophic levels, such as true midge larvae, mayfly nymphs, and zooplankton. The delta carbon-13 $\left(\delta^{13} \mathrm{C}\right)$ values measured in true midge larvae collected at the Lake Worth and upper and lower Woods Inlet sites were more negative compared with the $\delta^{13} \mathrm{C}$ values measured for all other taxa, indicating true midge larvae were more depleted of carbon-13 $\left({ }^{13} \mathrm{C}\right)$ compared with all other aquatic invertebrate and fish. The relative depletion of ${ }^{13} \mathrm{C}$ might indicate the carbon sources consumed by true midge larvae are different from the carbon sources consumed by all other taxon that were sampled. Ratios of stable nitrogen isotopes nitrogen- 15 to nitrogen-14 $\left(\delta^{15} \mathrm{~N}\right)$ were similar between taxa from the Lake Worth site and Woods Inlet sites. The sum of 15 PCB-congener concentrations, however, was an order of magnitude higher in largemouth bass from the upper Woods Inlet site, indicating that PCB-congener concentrations in lake bed sediment likely controls biomagnification within the lake because of the similarities in trophic structure of the resident aquatic community. The biota at the Lake Worth reference site, where PCBs were not detected in the surficial sediment during previous studies, were less contaminated than the biota at sites where PCBs had been detected in the surficial sediment. The highest trophic-level consumers (as evidenced by the most ${ }^{15} \mathrm{~N}$-enriched $\delta^{15} \mathrm{~N}$ values) showed the maximum bioaccumulation.

\section{Introduction}

The U.S. Geological Survey (USGS), in cooperation with the U.S. Air Force, investigated the concentrations of polychlorinated biphenyls (PCBs) in biota (aquatic invertebrates and fish) in selected areas of Lake Worth in Fort Worth, Tex. (including Woods Inlet, an arm of Lake Worth that extends south from the main body of the lake) and in Meandering Road Creek, a tributary to Lake Worth (fig. 1). PCB concentrations in biota samples were compared with PCB concentrations measured in surficial bed-sediment samples collected from approximately the same locations in previous USGS studies (Harwell and others, 2003; Besse and others, 2005; Braun and others, 2008). Aquatic invertebrate and fish samples were collected from four sites (site 004LW in the main body of Lake Worth, sites 002WI and 003WI in Woods Inlet, and site 001MC in Meandering Road Creek) and analyzed for selected PCBs. The sampling sites were selected to represent the range in PCB concentrations measured in surficial bed 

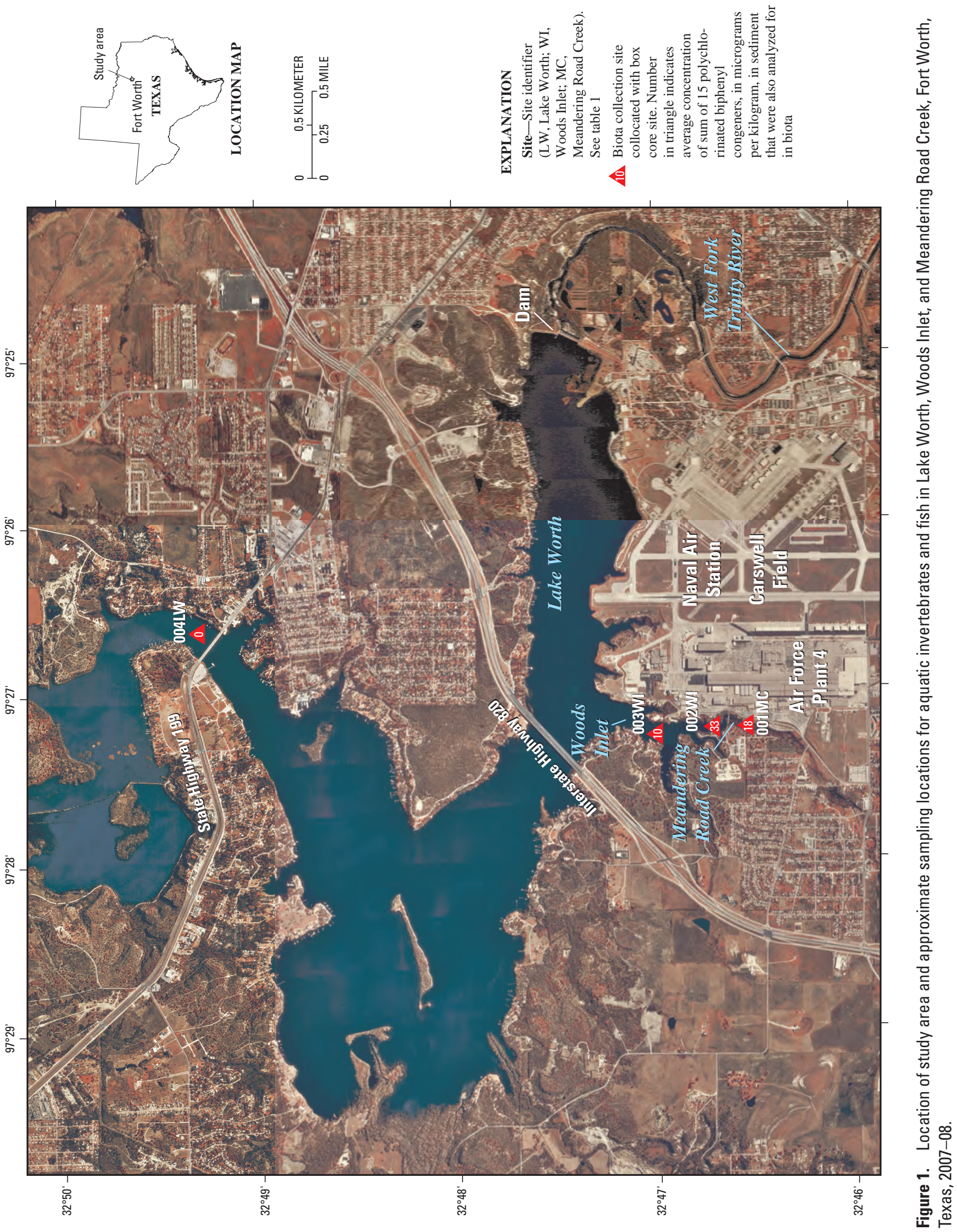
sediment in Lake Worth, Woods Inlet, and Meandering Road Creek in previous USGS studies.

PCBs are a class of chlorinated organic compounds, and there are 209 distinct PCB compounds called congeners, each with from 1 to 10 chlorine atoms attached to two benzene rings. From the 1920s until the late 1970s, about 130 PCB congeners were widely used in commercial PCB mixtures called Aroclors (Erickson, 1997). In August 2005, the Texas Commission on Environmental Quality (2005) issued a numeric target of 40 micrograms per kilogram $(\mu \mathrm{g} / \mathrm{kg})$ of total PCBs or less in edible fish tissues from Lake Worth. A reduction of PCB concentration in fish tissue to $40 \mu \mathrm{g} / \mathrm{kg}$ or less could ultimately allow the Texas Department of State Health Services to discontinue the existing fish consumption advisory for Lake Worth (Texas Department of State Health Services, 2000).

Total PCB concentrations in surficial bed-sediment samples collected from Woods Inlet in Lake Worth and near the Lake Worth Dam (fig. 1) have declined exponentially since 1960, and PCB concentrations in 2000 were about one-third of historical peak concentrations (Harwell and others, 2003). Despite those declines, mean total PCB concentrations in edible fish tissue from Lake Worth have remained about 6 times (Moring, 2002) to 10 times (Giggleman and Lewis, 2004) greater than the Texas Commission on Environmental Quality acceptable-risk target concentration in edible fish tissue of $40 \mu \mathrm{g} / \mathrm{kg}$.

The processes of bioaccumulation and biomagnification are the likely reasons PCB concentrations remain elevated in edible fish tissue despite declining sharply in the surficial bed sediment of Lake Worth. Bioaccumulation involves the accumulation of chemicals, such as PCBs, in the tissues of organisms as these chemicals are ingested. Biomagnification involves progressive increases in the concentrations of chemicals in the tissues of organisms as these chemicals are transferred up through two or more trophic levels in an ecosystem (Rand and Petrocelli, 1985). Trophic level refers to the position an organism or group of organisms occupy in a food web; trophic structure refers to the partitioning of biomass between groups of organisms occupying the same position in a food web (Preisser, 2008). As a result of biomagnification, lower concentrations of contaminants are generally found in organisms from lower trophic levels (in the same food web) compared with organisms from higher trophic levels. Each trophic level becomes more contaminated than the next lower trophic level, and the increase in contaminants up two or more trophic levels is often geometric or exponential in magnitude, particularly for compounds with limited water solubility (Dietz and others, 2000). Biomagnification also results in higher concentrations in organisms at higher trophic levels than would be expected if water were the only exposure medium (Gobas and Morrison, 2000). Fat-soluble (lipophilic) contaminants, such as PCBs, are known to biomagnify in aquatic food chains (Burreau and others, 1997; Russell and others, 1999; Rognerud and others, 2002; Borga and others, 2004). PCBs are highly persistent contaminants for which food [web] contributions rather than waterborne exposures are considered the most relevant exposure route for aquatic organisms (Carbonell and others, 2000).

The specialization of organisms in biological communities as food producers and consumers allows energy to flow and nutrients to cycle through the trophic structure (Ricklefs, 1979). The trophic structure of an aquatic community is defined by organisms representing different ecosystem functions and different trophic levels interacting in a complex food web; groups of organisms occupy trophic levels defined by the source of energy and nutrients for those organisms (Levine, 1980). In aquatic ecosystems, phytoplankton (suspended algae) are among the organisms at the lowest trophic level, converting energy from the sun into useable energy for other organisms; for this reason, phytoplankton are referred to as primary producers. Other primary producers are macrophytes (vascular aquatic plants) and periphytic (benthic) algae (algae growing on a submerged surface) (Kohzu and others, 2009). Invertebrates and fish are referred to as consumers, but they can be separated into additional trophic levels in freshwater systems, including herbivores (plant-eating organisms), referred to as primary consumers; invertivores (invertebrateeating organisms), referred to as secondary consumers; and piscivores (fish-eating organisms), referred to as tertiary consumers. Among herbivores are primary consumers occupying the lowest trophic level of all invertebrates; primary consumers serve as primary food items for other invertebrates and fish (Broman and others, 1992; Auster and others, 2005). In lakes, the range of food for primary consumers includes suspended particulate organic matter, benthic particulate organic matter, phytoplankton (suspended algae), vascular aquatic plants, and benthic algae.

Trophic levels have traditionally been expressed in discrete terms representing producers, primary consumers, secondary consumers, and tertiary consumers (Ricklefs, 1979), symbolized by whole numbers (typically from 1 to 4 , with 1 representing primary producers, 2 representing primary consumers, 3 representing secondary consumers, and 4 representing tertiary consumers). In more complex ecosystems, additional trophic levels symbolized by whole numbers from 5 to 8 are possible (Broman and others, 1992; Vander Zanden and Fetzer, 2007). Most organisms acquire energy and nutrients from more than one trophic level and thus likely represent an intermediate trophic level that can be symbolized by a nonwhole number, referred to as a trophic position.

Metabolic processes of animals enrich the heavy isotopes of nitrogen (nitrogen-15 $\left[{ }^{15} \mathrm{~N}\right]$ and carbon-13 $\left[{ }^{13} \mathrm{C}\right]$ ) relative to the lighter isotopes (nitrogen-14 $\left[{ }^{14} \mathrm{~N}\right]$ and carbon-12 $\left[{ }^{12} \mathrm{C}\right]$ ) (Broman and others, 1992). Because biomagnification of a contaminant can be related to trophic level or more precisely, trophic position, nitrogen isotope composition provides a means to understand the potential for contaminant biomagnification. Patterns of biomagnification of PCBs in aquatic invertebrates and fish can be identified from the relation between the PCB concentrations in an organism and the assigned 
trophic levels of one or more groups of organisms. When data are sufficient, trophic position calculated from the nitrogen isotope composition of an organism (Peterson and Fry, 1987) provides a precise measure of the organism's position in the trophic structure. Because carbon isotope composition is preserved through multiple trophic levels and positions of the food web, it can be used to indicate whether the principal source for biomagnification in a freshwater ecosystem is benthic (associated with sediment) or pelagic (associated with the overlying water column).

\section{Purpose and Scope}

This report describes the concentration of the sum of $15 \mathrm{PCB}$ congeners $\left(\sum \mathrm{PCB}_{\mathrm{C} 15}\right)$ in aquatic invertebrates and fish collected during 2007-08 from Lake Worth near Fort Worth (including Woods Inlet) and from Meandering Road Creek, a tributary to Lake Worth, and the use of stable isotopes of nitrogen and carbon (delta nitrogen- $15\left[\delta^{15} \mathrm{~N}\right]$ and delta carbon-13 $\left.\left[\delta^{13} \mathrm{C}\right]\right)$ in aquatic invertebrates and fish to make observations about trophic structure and patterns of bioaccumulation. Aquatic invertebrates and fish were collected at four sites where surficial bed-sediment samples had been collected and analyzed for PCBs in previous USGS studies (one site in the main body of Lake Worth, two in Woods Inlet, and one in Meandering Road Creek).

PCB concentrations $\left(\sum \mathrm{PCB}_{\mathrm{C} 15}\right)$ measured in composite samples of aquatic invertebrates and fish were compared with PCB concentrations measured in surficial bed-sediment samples collected from approximately the same locations as during previous USGS studies. Trophic levels and $\delta^{15} \mathrm{~N}$ and $\delta^{13} \mathrm{C}$ values were compared with PCB concentrations measured in composite samples of aquatic invertebrates and fish to make observations on how PCB concentrations varied depending on an organism's position in the food web. The Spearman rank correlation was used to evaluate the strength of the relation for the following pairs of variables: (1) $\sum \mathrm{PCB}_{\mathrm{C} 15}$ in surficial bed sediment and $\Sigma \mathrm{PCB}_{\mathrm{C} 15}$ in aquatic invertebrates and fish taxa (taxon [singular] or taxa [plural] refers to a genetically related group or groups of one or more organisms with common characteristics that differentiate them as a unit) (International Commission on Zoological Nomenclature, 2010) from sampling locations in Lake Worth, Woods Inlet, and Meandering Road Creek; and (2) $\delta^{15} \mathrm{~N}$ and $\sum \mathrm{PCB}_{\mathrm{C} 15}$ in composite samples of aquatic invertebrate and fish taxa collected from sampling locations in Lake Worth, Woods Inlet, and Meandering Road Creek.

Because PCBs are mostly found in sediment, only contributions of PCBs derived from surficial bed-sediment food sources were considered; any waterborne contributions to PCB concentrations in aquatic invertebrates and fish were not evaluated. Effects of differences in age, rates of growth, and diet on the PCB concentrations and other similar contaminants in aquatic invertebrates and fish were beyond the scope of the study.

\section{Description of Study Area}

Lake Worth is a reservoir on the West Fork Trinity River on the western outskirts of Fort Worth, Tex. (fig. 1). In 1914, the City of Fort Worth completed the reservoir to serve as a municipal water supply; the reservoir also is used for fishing and recreation (City of Fort Worth, Texas, 2010). Lake Worth has a storage capacity of 47 million cubic meters, a surface area of 13.2 square kilometers, and a contributing watershed that drains 5,320 square kilometers (Ruddy and Hitt, 1990). The area adjacent to the lake to the south and east is mostly urban, to the north and northwest mostly residential, and to the west mostly rangeland. Lake Worth is in the Cross Timbers Level III ecoregion (Omernick, 1987) and is a warm-water fishery dominated by fish such as catfish, crappie, and largemouth bass.

Air Force Plant 4 (AFP4) is on the south shore of Lake Worth and adjacent to Woods Inlet and Meandering Road Creek (fig. 1). Since 1942, aircraft manufacturing operations and processes at AFP4 have generated waste materials (fuels, oils, solvents, paint residues, and process chemicals) that were disposed of on-site (Texas Department of Health, 1998). Two PCB leaks or spills, one in 1984 and the other in 1989, have been documented on the western side of AFP4 adjacent to Meandering Road Creek (Earth Tech Inc., 2005).

\section{Previous Studies}

PCB-contaminated runoff has historically drained from AFP4 to Meandering Road Creek, which flows into the Woods Inlet of Lake Worth (Harwell and others, 2003; Besse and others, 2005; Braun and others, 2008; Braun and Wilson, 2010). In April 2000, the Texas Department of Health issued a fish consumption advisory for Lake Worth because of elevated concentrations of PCBs in the edible tissues of selected species of fish (Texas Department of State Health Services, 2000). Potential sources of PCBs to Lake Worth (main body and Woods Inlet) and Meandering Road Creek include historical landfills or historically contaminated soils on AFP4 (Besse and others, 2005). Harwell and others (2003) analyzed surficial bed sediment collected from sites throughout much of Lake Worth for PCBs. Total PCB concentrations $\left(\sum \mathrm{PCB}_{\mathrm{Cl} 5}\right)$ in surficial bed sediment ranged from less than the laboratory minimum reporting level of $60 \mu \mathrm{g} / \mathrm{kg}$, the level used for the analysis of samples collected in the main body of Lake Worth (Harwell and others, 2003, p. 56-66), to $450 \mu \mathrm{g} / \mathrm{kg}$ in Woods Inlet and $170 \mu \mathrm{g} / \mathrm{kg}$ in Meandering Road Creek (Braun and others, 2008, p. 33-38). The highest PCB concentrations in surficial bed sediment were measured at sites in Woods Inlet, whereas no detections of PCBs were reported at sites in the main body of the lake north of the Interstate Highway 820 bridge. Besse and others (2005) reported that the highest PCB concentrations in surficial bed sediment in Woods Inlet were near the mouth of Meandering Road Creek. Braun and others (2008) reported detections of PCBs in surficial bed sediment 
of Meandering Road Creek and, consistent with Besse and others (2005), the highest PCB concentrations were detected in Woods Inlet near the mouth of Meandering Road Creek. On the basis of PCB concentrations measured in suspended sediment at sites on AFP4 near Meandering Road Creek and in surficial bed-sediment samples collected in the creek and Woods Inlet, Braun and others (2008) concluded that PCBs probably entered Woods Inlet primarily from Meandering Road Creek, and that runoff from AFP4 is a prominent source of PCBs in Meandering Road Creek and Woods Inlet. Braun and Wilson (2010) investigated PCBs in suspended-sediment samples in storm runoff from outfalls 4 and 5, which drain into Meandering Road Creek at AFP4, and found evidence that PCB concentrations in storm runoff from AFP4 have decreased since engineering controls were implemented during 2007-08.

\section{Methods of Investigation}

Aquatic invertebrates and fish were collected during 2007-08 at the following four sites: 004LW Lake Worth near State Highway 199 bridge (hereinafter, Lake Worth); 003WI Lake Worth in lower Woods Inlet (hereinafter, lower Woods Inlet); 002WI Lake Worth in upper Woods Inlet (hereinafter, upper Woods Inlet); and 001MC Meandering Road Creek near confluence with Lake Worth (hereinafter, Meandering Road Creek) (fig. 1; table 1). These sites are at approximately the same locations where surficial bed-sediment samples were collected and analyzed for PCBs in previous USGS studies (Harwell and others, 2003; Besse and others, 2005; Braun and others, 2008). PCB concentrations in surficial sediment are often positively correlated with the level of exposure of many aquatic invertebrates and fish to PCBs (Fowler and others, 1978; Larsson, 1984; Helm and others, 2008). The four sampling sites for aquatic invertebrates and fish were selected to provide a variety of relatively deep water (more than 2 meters) and near-shore habitat. A composite sample of each taxon from each site was analyzed for ${ }^{15} \mathrm{~N},{ }^{14} \mathrm{~N},{ }^{13} \mathrm{C},{ }^{12} \mathrm{C}$, and 15 PCB congeners. Composite samples were used instead of individual organisms because it was cost prohibitive to collect and analyze individual organisms of multiple taxa across the four sites for this study. The upper and lower Woods Inlet sampling sites were selected because these sites had some of the highest PCB concentrations measured in surficial-sediment samples during previous USGS studies. The Lake Worth sampling site was selected as a reference site because PCBs had not been detected in surficial-sediment samples collected at this site during previous USGS studies. The Meandering Road Creek sampling site for invertebrates and fish is a reach about 100 meters long immediately west of AFP4, about 30 meters upstream from Woods Inlet, and at or near three previously sampled sediment sites (Braun and others 2008). The Meandering Road Creek site for biota sampling was selected because PCBs were detected at concentrations exceeding the laboratory minimum reporting level in surficial-sediment samples collected from the same reach of the creek during previous USGS studies, and because aquatic invertebrates and fish in the creek had not been sampled historically and would likely provide different taxa than the lake sampling sites. Site location information and sample size of aquatic invertebrate and fish taxa collected at the four sites during 2007-08 are listed in table 1. All data from the discrete environmental

Table 1. Description of sampling sites and sample size of aquatic invertebrate and fish taxa collected in Lake Worth, Woods Inlet, and Meandering Road Creek, Fort Worth, Texas, 2007-08.

[(2, 3, or 4), trophic level; LW, Lake Worth; >, greater than; ---, no data; WI, Woods Inlet; MC, Meandering Road Creek]

\begin{tabular}{|c|c|c|c|c|c|c|c|c|c|c|c|c|}
\hline \multirow{2}{*}{ Site description } & \multirow{2}{*}{$\begin{array}{l}\text { Site } \\
\text { identi- } \\
\text { fier } \\
\text { (fig. 1) }\end{array}$} & \multirow{2}{*}{$\begin{array}{l}\text { Latitude } \\
\text { (degrees } \\
\text { minutes } \\
\text { seconds) }\end{array}$} & \multirow{2}{*}{$\begin{array}{l}\text { Longitude } \\
\text { (degrees } \\
\text { minutes } \\
\text { seconds) }\end{array}$} & \multicolumn{4}{|c|}{$\begin{array}{l}\text { Number collected per } \\
\text { invertebrate taxon } \\
\text { (trophic level), } \\
\text { August } 2007\end{array}$} & \multicolumn{5}{|c|}{$\begin{array}{l}\text { Number collected per fish taxon } \\
\text { (trophic level), } \\
\text { September } 2007\end{array}$} \\
\hline & & & & $\begin{array}{l}\text { True } \\
\text { midge } \\
\text { larvae } \\
\text { (2) }\end{array}$ & $\begin{array}{l}\text { Zoo- } \\
\text { plank- } \\
\text { ton' } \\
(2 \text { or } 3)\end{array}$ & $\begin{array}{c}\text { Mayfly } \\
\text { nymphs } \\
\text { (2) }\end{array}$ & $\begin{array}{l}\text { Dragon- } \\
\text { fly } \\
\text { nymphs } \\
(3)\end{array}$ & $\begin{array}{c}\text { Large- } \\
\text { mouth } \\
\text { bass } \\
(4)\end{array}$ & $\begin{array}{l}\text { Green } \\
\text { sun- } \\
\text { fish } \\
(3)\end{array}$ & $\begin{array}{l}\text { Longear } \\
\text { sunfish } \\
\text { (3) }\end{array}$ & $\begin{array}{c}\text { Western } \\
\text { mosqui- } \\
\text { tofish } \\
\text { (3) }\end{array}$ & $\begin{array}{c}\text { Gizzard } \\
\text { shad } \\
(3)\end{array}$ \\
\hline $\begin{array}{l}\text { Lake Worth in lower } \\
\text { Woods Inlet }\end{array}$ & 003WI & $32^{\circ} 46^{\prime} 59.8^{\prime \prime}$ & $97^{\circ} 27^{\prime} 17.1^{\prime \prime}$ & 90 & $>500$ & --- & --- & 10 & --- & 15 & --- & --- \\
\hline $\begin{array}{l}\text { Lake Worth in upper } \\
\text { Woods Inlet }\end{array}$ & 002WI & $32^{\circ} 46^{\prime} 41.5^{\prime \prime}$ & $97^{\circ} 27^{\prime} 15.7^{\prime \prime}$ & 45 & $>500$ & --- & --- & 10 & --- & 10 & --- & 10 \\
\hline
\end{tabular}

${ }^{1}$ Water fleas and copepods. 
samples, including results for quality control, are published in the USGS National Water Information System (NWIS) (U.S. Geological Survey, 2010). Consistent with all previous USGS studies done at Lake Worth and AFP4 (Harwell and others, 2003; Besse and others, 2005; Braun and others, 2008; Braun and Wilson, 2010), estimated PCB congener concentrations were used as reported, and values less than the method detection limit were treated as zeros.

All statistical analyses and graphics were done with Statistica Version 7.0. The Spearman rank correlation (rho) was used to measure the strength of the monotonic association between various pairs of variables (Lehmann and D'Abrera, 1998; StatSoft, 2006). Spearman rank correlation is a nonparametric statistical analysis that uses a rank correlation procedure to evaluate the relation between two variables even if that relation is not necessarily linear (Ott, 1993).

\section{Collection and Processing of Samples}

Aquatic invertebrate and fish samples were collected in order of lowest to highest expected PCB concentrations, based on PCB concentrations measured in surficial sediment in previous USGS studies by Harwell and others (2003), Besse and others (2005) and Braun and others (2008), to minimize cross-site contamination. The first site sampled was Lake Worth, the site with the lowest PCB concentrations in surficial sediment. The last site sampled was upper Woods Inlet, the site with the highest concentrations in surficial sediment. All sampling equipment was detergent washed, solvent rinsed with methanol, and rinsed with deionized water between sites (Moring, 2002). All sampling equipment and sample containers were triple rinsed with ambient water at each site before sample collection. All aquatic invertebrates and fish, except for zooplankton, were collected in late August and early September 2007. Zooplankton samples were collected in April 2008. Biota samples were composited, freeze-dried, ground, and analyzed for the following: 15 PCB congeners, the ratio of ${ }^{15} \mathrm{~N}$ to ${ }^{14} \mathrm{~N}$ (expressed as $\delta^{15} \mathrm{~N}$ ), and the ratio of ${ }^{13} \mathrm{C}$ to ${ }^{12} \mathrm{C}$ (expressed as $\delta^{13} \mathrm{C}$ ).

\section{Collection of Aquatic Invertebrate Samples}

The different taxa of aquatic invertebrates targeted for collection at the Lake Worth, upper and lower Woods Inlet, and Meandering Road Creek sites were selected because they are primary or secondary consumers that serve as the most likely trophic pathway (contribution by food ingestion) for the biomagnification of PCBs from surficial sediment to secondary and tertiary consumers (Joaquim-Justo and others, 1995). Aquatic invertebrates targeted for collection at the Lake Worth and upper and lower Woods Inlet sites included true midge larvae (table 1) that inhabit surficial lake sediment during the larval stage and pelagic zooplankton that inhabit the water column over their entire life cycle. The true midge larvae (hereinafter midge larvae) collected at the
Lake Worth and upper and lower Woods Inlet sites were of the subfamily Chironominae. Members of this taxon are collectors and filter feeders (Merritt and Cummins, 1996) that ingest surficial and suspended sediment. The invertebrates collected at the Meandering Road Creek site were mayfly nymphs and dragonfly nymphs (table 1). Mayflies collected at the Meandering Road Creek site are in the family Caenidae and are collector-gatherers or scrapers feeding on periphyton and organic detritus on the surface of rocks and other substrates. Dragonfly nymphs of the suborder Anisoptera are predators and feed on other invertebrates (Resh and Rosenberg, 1984).

Midge larvae were collected from surficial sediment at the Lake Worth and upper and lower Woods Inlet sites with a 15 - by 15 - by 23 -centimeter stainless-steel box corer by following methods similar to Hogan (2002). The weighted box corer was lowered from a boat into the surficial sediment of the lake bottom and retrieved. The contents of the box corer were placed in a 500-micrometer mesh stainless-steel sieve tray. The sediment was rinsed in the sieve tray with ambient water; and the midge larvae were collected, placed in a labeled polypropylene container, and frozen on-site with dry ice. Box coring was repeated within a 300-meter radius of each site until a minimum of 3 grams wet weight of midge larvae was measured at each of the sites.

Zooplankton were collected at the Lake Worth and upper and lower Woods Inlet sites with a 200-micrometer mesh plankton net by following methods similar to those described in Britton and Greeson (1989). Three horizontal plankton tows were taken within a 300-meter radius of each site. Each tow involved lowering the plankton net to a depth of 1-3 meters and towing the net for approximately 100 meters with a boat. At the end of each tow, the contents of the net were placed in a labeled polypropylene container. Each composite sample was weighed to the nearest gram, entrained organic and inorganic debris removed, the sample homogenized by stirring, and a 5-gram zooplankton subsample retained and frozen on-site with dry ice. Frozen zooplankton samples were returned to the USGS Texas Water Science Center in Austin, Tex., thawed, identified and counted. Zooplankton in each sample included members of the orders Cladocera (water fleas) and Copepoda (copepods) (table 1). Water fleas range from 0.2 to 3.0 millimeters in length and are filter feeders that consume algae, bacteria, and organic detritus (Pennak, 1989). Copepods range from 0.3 to 3.2 millimeters in length; those collected in this study included filter feeders (calanoid copepods) that feed on other plankton, and predators (cyclopoid copepods) that feed by biting and seizing other organisms (Pennak, 1989). Copepods were the dominant zooplankton taxon in all samples.

All nymphs from the Meandering Road Creek site were collected with a 500-micrometer mesh, D-frame dip net (Moulton and others, 2002) in coarse bed material that ranged from large gravel to small cobble, and the nymphs were placed in polypropylene containers. Sampling was continued until a minimum of about 2 grams wet weight of mayfly and 
dragonfly nymphs were collected, and the samples were frozen on-site with dry ice.

\section{Collection of Fish Samples}

The taxa of fish targeted for collection at the four sites were chosen to represent the types of predator and prey trophic interactions expected to contribute to the biomagnification of PCBs. Fish targeted for collection at the Lake Worth and upper and lower Woods Inlet sites included the following: Micropterus salmoides (largemouth bass), a tertiary consumer and piscivore; Lepomis megalotis (longear sunfish), a secondary consumer, invertivore, and potential prey for largemouth bass; and Dorosoma cepedianum (gizzard shad), a secondary consumer, planktivore, and potential prey for largemouth bass (table 1). No gizzard shad were collected at the lower Woods Inlet site. Fish species targeted for collection at the Meandering Road Creek site included largemouth bass and longear sunfish; Lepomis cyanellus (green sunfish) and Gambusia affinis (western mosquitofish) were also collected at the Meandering Road Creek site to better represent the different types of fish and thus better represent the trophic structure in Meandering Road Creek (table 1). Fish were collected by boat electrofishing near shore at the Lake Worth and upper and lower Woods Inlet sites and with a backpack electrofishing unit at the Meandering Road Creek site. Electrofishing, in this study, involved the use of direct current (DC) applied to the water with anode and cathode arrays (Moring, 2002). At the Lake Worth and upper and lower Woods Inlet sites, fish were collected in and around near-shore woody snags, boat docks, and concrete riffraff in an area ranging from 50 to 300 meters from the sediment collection site associated with each area (fig. 1). Fish were collected from multiple habitat types at the Meandering Road Creek site, including the main channel and channel margins of riffles, runs, and pools over a reach of about 100 meters in length, by using methods similar to those described in Moring (2006).

Each fish was individually identified by species, measured for its total and standard length (Nielsen and Johnson, 1983 , p. 284-285) to the nearest millimeter, weighed to the nearest gram, rinsed with deionized water, double-wrapped in heavy-duty aluminum foil, labeled, and frozen on-site with dry ice. A fish sample for each species and site was prepared by combining the largest fish (whole body samples) that also were of a distinct size class into a single composite sample of ground tissue. Fish sample sizes ranged from 4 to 23 fish per sample; controlling for an equal size class of fish in each sample was thought to be more important than an equal number of fish, of varying size and age, in each composite.

\section{Processing of Aquatic Invertebrate and Fish Samples}

Upon return to the Texas Water Science Center in Austin, study personnel thawed all aquatic invertebrate and fish samples, and a minimum of 0.4 gram wet weight was subsampled for the determination and quantitation of the PCB congeners. For biological tissue, 1 gram wet weight is normally required for the analysis of PCB congeners, but several aquatic invertebrate samples were less than 1 gram; therefore, a minimum sample weight of 0.4 gram was determined to be acceptable for the analysis of PCB congeners in biological samples (Mark Burkhardt, U.S. Geological Survey, written commun., 2008). To obtain the minimum of 0.4 gram needed for PCB analyses, from 1 to 47 individual organisms per sample were included, depending on the taxon. A minimum of 0.003 gram wet weight was subsampled from each composite sample for the analysis of stable isotopes ${ }^{15} \mathrm{~N},{ }^{14} \mathrm{~N},{ }^{13} \mathrm{C}$, and ${ }^{12} \mathrm{C}$ (Carol Kendall, U.S. Geological Survey, written commun., 2008). To obtain the minimum of 0.003 gram needed for the isotope analyses, from 2 to 45 individual organisms per sample were included, depending on the taxon. The subsamples were refrozen pending shipment to the USGS National Water Quality Laboratory (NWQL) in Lakewood, Colo., for the analysis of PCBs, or the USGS Isotope Research Laboratory in Menlo Park, Calif., for the analysis of stable nitrogen and carbon isotopes.

\section{Analysis of Polychlorinated Biphenyl Congeners}

The USGS NWQL analyzed the invertebrate and fish samples for 15 PCB congeners (appendix 3) using a custom analytical method; custom methods have not been completely evaluated with USGS guidelines for developing official methods. To analyze PCB-congener concentrations, each invertebrate and fish sample was solvent-extracted by using a pressurized solvent-extraction system, and the 15 PCB congeners of interest were extracted from interfering matrix components by using a high-pressure water/isopropyl alcohol extraction and were isolated by using disposable solid-phase extraction (SPE) cartridges. The cartridges were air-dried, and sorbed PCB congeners were eluted with methylene chloride and diethyl ether through a florisil/alumina/sodium sulfate SPE cartridge and reduced in volume to approximately 0.5 milliliter under a nitrogen stream. The reduced volume extract was solvent-exchanged into hexane. The hexane extract was reduced to approximately 0.5 milliliter, and the analytes were determined and quantitated by using negative chemical gas chromatography/mass spectrometry (Mark Burkhardt, U.S. Geological Survey, written commun., 2008). For convenience, the sum of the concentration of 15 PCB congeners is referred to as $\sum \mathrm{PCB}_{\mathrm{C} 15}$ throughout this report.

$\mathrm{PCB}$-congener concentrations measured in biota samples for this study were compared with PCB-congener concentrations measured in surficial-sediment samples collected during 2000-2001 from Lake Worth (Harwell and others, 2003) and with PCB-congener concentrations in surficialsediment samples collected in 2006 from Woods Inlet and Meandering Road Creek (Braun and others, 2008). Harwell and others (2003) collected 21 surficial-sediment samples 
from 21 sampling locations during 2000-2001 in Lake Worth (including the Lake Worth and Woods Inlet sites sampled for invertebrates and fish described in this report) with a 14- by 14- by 20-centimeter Wildco box corer that penetrated about 20 centimeters into the sediment. Braun and others (2008) collected sediment samples in 2004 and 2006-07 during as many as three storms at four to five sites (depending on flow conditions) that provide inflow to Meandering Road Creek and collected surficial-sediment samples for the analysis of PCBs from 20 sites distributed between Meandering Road Creek and Woods Inlet.

PCBs in the sediment samples collected during 20002001 (Harwell and others, 2003) were determined and quantitated as Aroclor mixtures 1242, 1254, and 1260. Laboratory minimum reporting levels ranged from 5 to $20 \mu \mathrm{g} / \mathrm{kg}$ for each Aroclor, depending on sample mass, sample matrix, and analytical interference (Harwell and others, 2003, p. 33); for $\sum \mathrm{PCB}_{\mathrm{C} 15}$, the laboratory minimum reporting level was $60 \mu \mathrm{g} / \mathrm{kg}$. Estimated values are detections equal to or greater than the laboratory method detection limit and less than the laboratory minimum reporting level. Estimated values differ from other quantitative values because the laboratory cannot report the estimated value with the same level of confidence. Values were reported as less than the laboratory minimum reporting level when the constituent was not measured in the sample at a concentration equal to or greater than the laboratory method detection limit; the constituent might have been present at concentrations less than the laboratory minimum reporting level but greater than the laboratory method detection limit, but interferences prevented detection (Childress and others, 1999).

\section{Analysis of Stable Nitrogen and Carbon Isotopes}

Stable isotope ratios are measured as the ratio of the two most abundant isotopes of a given element. The most abundant isotopes of nitrogen are ${ }^{15} \mathrm{~N}$ and ${ }^{14} \mathrm{~N}$, whereas the most abundant isotopes of carbon are ${ }^{13} \mathrm{C}$ and ${ }^{12} \mathrm{C}$ (Clark and Fritz, 1997). The USGS Isotope Tracers Project (U.S. Geological Survey, 2004) provides the following description of stable isotope compositions: "The stable isotopic compositions of low-mass (light) elements, such as oxygen, hydrogen, carbon, nitrogen, and sulfur, are normally reported as "delta" $(\delta)$ values in parts per thousand (denoted as \%o) enrichments or depletions relative to a standard of known composition. The symbol \%o is spelled out in several different ways: permil, per mil, per mill, or per mille. The term "per mill" is the [International Standards Organization] term, but is not yet widely used."

Procedures used for the analysis of stable nitrogen and carbon isotopes are described by Kendall and others (2001). Isotope composition was reported in "\%" units. Nitrogen isotopic compositions are expressed in $\delta^{15} \mathrm{~N}$ relative to atmospheric nitrogen $\left(\mathrm{N}_{2}\right)$ and are reported with a laboratory analytical precision of $0.2 \%$. $\delta^{15} \mathrm{~N}$ expresses the ratio of the heavier $\left({ }^{15} \mathrm{~N}\right)$ to the lighter $\left({ }^{14} \mathrm{~N}\right)$ isotope in a sample to the same ratio in a reference standard:

$$
\delta^{15} \mathrm{~N}=\left\{\left[\left({ }^{15} \mathrm{~N} /{ }^{14} / \mathrm{N}\right)_{\mathrm{X}} /\left({ }^{15} \mathrm{~N} /{ }^{14} / \mathrm{N}\right)_{\text {Air }}\right]-1\right\} * 1,000,
$$

where

$$
\mathrm{x}=\text { sample, and }
$$

Air $=$ atmospheric nitrogen $\left(\mathrm{N}_{2}\right)$.

Carbon isotopic compositions are expressed in $\delta^{13} \mathrm{C} \%$ relative to the Vienna PeeDee Belemnite International carbon standard (Hut, 1987) to express the ratio of the heavier $\left({ }^{13} \mathrm{C}\right)$ to the lighter $\left({ }^{12} \mathrm{C}\right)$ isotope in a sample to the same ratio in a reference standard:

$$
\delta^{13} \mathrm{C}=\left\{\left[\left({ }^{13} \mathrm{C} /{ }^{12} / \mathrm{C}\right)_{\mathrm{x}} /\left({ }^{13} \mathrm{C} /{ }^{12} / \mathrm{C}\right)_{\mathrm{VPDB}}\right]-1\right\}^{*} 1,000,
$$

where

$\mathrm{x}=$ sample, and

VPDB $=$ Vienna Pee Dee Belemnite International carbon standard.

Using nitrogen isotopes as an example, if an organism has a higher ${ }^{15} \mathrm{~N} /{ }^{14} \mathrm{~N}$ ratio than the ${ }^{15} \mathrm{~N} /{ }^{14} \mathrm{~N}$ ratio of the reference standard (nitrogen in air), $\delta^{15} \mathrm{~N}$ will be positive; $\delta^{15} \mathrm{~N}$ will be negative if the isotope ratio of the sample is less than that of the standard. A $\delta^{15} \mathrm{~N}$ value of $+30 \%$ means that there are 30 parts per thousand or 3 percent more ${ }^{15} \mathrm{~N}$ in the sample relative to the standard (U.S. Geological Survey, 2004).

Samples were thawed at room temperature. The organic matter was placed in 10-milliliter plastic screw-top vials and freeze-dried. The freeze-dried samples were ground using a ball mill with a 0.63 -centimeter stainless-steel ball. About 0.5 milligram of freeze-dried sample was weighed into 3- by 5 -millimeter tin capsules. Weights and sample positions were recorded on a sample weighing form. The samples were analyzed by combustion in an elemental analyzer at 1,050 degrees Celsius $\left({ }^{\circ} \mathrm{C}\right)$. The resulting gases were separated in a gas chromatograph column and the $\mathrm{N}_{2}$ and carbon dioxide $\left(\mathrm{CO}_{2}\right)$ were compared with reference gases by using a continuous flow mass spectrometer. Sample data, including the ratio of stable nitrogen isotopes $\left(\delta^{15} \mathrm{~N}\right)$ and the ratio of stable carbon isotopes $\left(\delta^{13} \mathrm{C}\right)$, were corrected for drift and linearity and entered into a database maintained at the USGS Isotope Research Laboratory in Menlo Park; observations about sample collection, preparation, and analysis were included in the database.

\section{Quality Control}

Three duplicate samples (subsamples) were analyzed: one invertebrate sample (a dragonfly nymph sample at the Meandering Road Creek site) and two composite fish samples (a longear sunfish sample at the Lake Worth site and a green sunfish sample at the upper Woods Inlet site). These quality control samples were used to evaluate potential bias, variability, or contamination introduced during sample preparation and laboratory analysis (appendix 1). Duplicate analyses for the dragonfly nymph and longear sunfish samples consisted of nitrogen and carbon isotopes. Duplicate analyses for the green sunfish sample consisted of 15 PCB congeners. Laboratory 
surrogate compound and spike recovery rates and laboratory blank samples were also used to evaluate the precision and accuracy of laboratory analyses (appendix 2).

Results obtained for duplicate environmental samples were compared with those of the original environmental samples by calculating the relative percent difference (RPD) for each pair of detected constituents (appendix 1). The RPD was calculated as the difference between the environmental and duplicate samples divided by the average of the two values and is expressed as a percentage:

$$
\mathrm{RPD}=\left|\left(\mathrm{C}_{1}-\mathrm{C}_{2}\right)\right| /\left(\left(\mathrm{C}_{1}+\mathrm{C}_{2}\right) / 2\right) \times 100
$$

where

$\mathrm{C}_{1}=$ concentration from environmental sample; and

$\mathrm{C}_{2}=$ concentration from duplicate sample.

The RPD between the original dragonfly nymph sample and its duplicate was 1.17 percent for nitrogen, 3.59 percent for carbon, 14.64 percent for $\delta^{15} \mathrm{~N}$, and -0.11 percent for $\delta^{13} \mathrm{C}$ (appendix 1). The RPD between the original longear sunfish and its duplicate was 11.07 percent for nitrogen, 10.57 percent for carbon, 6.93 percent for $\delta^{15} \mathrm{~N}$, and -8.27 percent for $\delta^{13} \mathrm{C}$. All RPD results were considered acceptable; RPDs less than 10 percent between an original and duplicate sample for stable isotopes are considered excellent results for biological tissues media (Steven Silva, U.S. Geological Survey, written commun., 2010).

The green sunfish composite sample from the upper Woods Inlet site was randomly selected for a comparison of the RPD between an original sample and a duplicate sample for the 15 PCB congeners analyzed in this study. The RPD ranged from 16.05 to 45.51 percent with a median RPD of 26.45 percent (appendix 1). No adjustments were made to the PCB-congener data based on the results for green sunfish. The composite sample used for comparison with a duplicate from the same samples was randomly selected from all the aquatic invertebrate and fish composite samples from the study. The RPD for concentration of an organic compound, such as a PCB congener, is considered acceptable if it is less than 35 percent; RPDs between 25 and 35 percent are common for PCB congeners in biological tissue samples (Steven Zaugg, U.S. Geological Survey, written commun., 2010). All samples in this study were composite samples that were homogenized prior to analysis; RPDs greater than 10 percent might indicate incomplete homogenization of the sample prior to subsample collections, but some degree of incomplete homogenization is typical for natural, nonreference material samples. No adjustments were made to the invertebrate or fish isotope data based on these results (Steven Silva, U.S. Geological Survey, written commun., 2010).

The analytical precision of stable isotopes of nitrogen and carbon was evaluated for each set of environmental samples by analyzing a set of ethylenediaminetetraacetic acid (EDTA) standard reference material samples calibrated with respect to VPDB for carbon isotopes and to atmospheric $\mathrm{N}_{2}$ for nitrogen isotopes. Paulson and others (2006, p. 27) describes the EDTA standard and explains how it is calibrated:

The working standard (EDTA) (41.09 percentage carbon by weight, 9.59 percentage $\mathrm{N}$ by weight) is calibrated with respect to VPDB for carbon isotopes and to atmospheric $\mathrm{N}_{2}$ for nitrogen isotopes $\left(\delta^{15} \mathrm{~N}=\right.$ $0.7 \%$ and $\delta^{13} \mathrm{C}=-32.2 \%$ ) [using several] International standards... [International Atomic Energy Agency and USGS standards for $\delta^{15} \mathrm{~N}$; National Bureau of Standards and International Atomic Energy Agency standards for $\left.\delta^{13} \mathrm{C}\right]$. A size-series of EDTA bracketing the nitrogen and carbon content of the samples [is] analyzed at an interval of every 10 samples and used for drift corrections and offsets of isotopic ratios and elemental composition.

Standard deviations of the EDTA sample sets were $0.19 \%$ o for percentage of nitrogen, $0.12 \%$ o for $\delta^{15} \mathrm{~N}, 0.30 \%$ o for percentage of carbon, and $0.05 \%$ for $\delta^{13} \mathrm{C}$. For the invertebrate and fish samples analyzed for this study, the standard deviations of the EDTA sample sets indicated acceptable levels of precision for the isotope constituents (Steven Silva, U.S. Geological Survey, written commun., 2010).

To evaluate the accuracy of the extraction process, selected PCB congeners and chlorinated pesticides were added in the laboratory as surrogates to blank and environmental samples. The average surrogate recoveries were 57.4 percent for 1,1'-bis( $p$-chlorophenyl)-2,2,2-trichloroethane (DDT- $d 8$ ) and 73.6 percent for 2,2',3,3',5,5',6,6'-octachlorobiphenyl (PCB 202-13C12); all surrogate recoveries are listed in appendix 2. Because a new, custom analytical method was used, acceptable ranges for spike and surrogate recoveries had not been established, and no past results using the same analytical method were available for comparison. The recovery of surrogate compounds is monitored by the laboratory with every set of at least 12 environmental samples (Mark Burkhardt and Steven Zaugg, U.S. Geological Survey, National Water Quality Laboratory, written commun., 2008).

One laboratory blank sample was analyzed for the 15 PCB congeners. All PCB-congener concentrations in the blank sample were quantified at values less than the applicable PCBcongener method detection limit (shown as a nondetection in appendix 2), which ranged from 0.1 to $5.0 \mu \mathrm{g} / \mathrm{kg}$.

Laboratory spike samples were analyzed for constituent concentrations by gas chromatography and mass spectrometry. The percentage of recovery for environmental samples spiked with PCB congener 202-13C12 ranged from 68 to 76 percent, which was similar to the range of average percentage recovery of 64 to 75 percent for the PCB congeners analyzed in the aquatic invertebrate and fish samples (appendix 2). No corrections were made to the PCB data on the basis of spiked recovery results.

All the sediment data used in this report were collected during previous USGS studies. Quality control for the analysis of sediment samples is described in Harwell and others (2003) and Braun and others (2008). 


\section{Polychlorinated Biphenyls in Aquatic Invertebrates and Fish}

PCBs are hydrophobic, readily adsorb to fine sediment and other particulates, and presumably would be most bioavailable from surficial sediment in Lake Worth (main body and Woods Inlet) and in Meandering Road Creek. Invertebrates and fish are continually exposed to these sediments directly or indirectly through the aquatic food chain.

The concentration of $\sum \mathrm{PCB}_{\mathrm{C} 15}$ ranged from $171.8 \mu \mathrm{g} / \mathrm{kg}$ in largemouth bass from the upper Woods Inlet site to a nondetection in midge larvae from the Lake Worth site (table 2). The concentration of $\sum \mathrm{PCB}_{\mathrm{C} 15}$ in midge larvae from the upper Woods Inlet site was $55.0 \mu \mathrm{g} / \mathrm{kg}$, more than 2 times the concentration of $23.6 \mu \mathrm{g} / \mathrm{kg}$ from the lower Woods Inlet site and about an order of magnitude higher than $\sum \mathrm{PCB}_{\mathrm{C} 15}$ in zooplankton from the Lake Worth and upper and lower Woods Inlet sites $(1.36$ to $4.09 \mu \mathrm{g} / \mathrm{kg})$. The concentration of $\sum \mathrm{PCB}_{\mathrm{C} 15}$ was highest in fish taxa from the upper Woods Inlet sites and lowest for all taxa from the Lake Worth site (table 2). PCBs were detected in largemouth bass, longear sunfish, gizzard shad, and zooplankton from the Lake Worth site, even though PCBs were not detected in the surficial-sediment samples collected previously from the site (Harwell and others, 2003) (fig. 2). The detection of PCBs in zooplankton and fish from the Lake Worth site, despite the fact PCBs were not detected in the surficial sediment at this site in previous USGS studies, is likely the result of biomagnification of PCBs during predatorprey interactions with progressive accumulation of PCBs from lower trophic levels, represented by invertebrates, to higher trophic levels, represented by fish. Low PCB concentrations (less than the laboratory minimum reporting levels) might be present in surficial sediment at Lake Worth, facilitating biomagnification of PCBs near this site.
The minimum reporting level used by the laboratory for the analysis of PCBs in surficial-sediment samples collected in Lake Worth during previous USGS studies was higher $(60 \mu \mathrm{g} / \mathrm{kg})$ compared with some of the minimum reporting levels used by the laboratory at other sites at Lake Worth and Meandering Road Creek for surficial bed-sediment samples, which ranged from 15 to $75 \mu \mathrm{g} / \mathrm{kg}$, and much higher compared with the minimum reporting levels for PCBs in aquatic invertebrates and fish, which ranged from 0.1 to $10.0 \mu \mathrm{g} / \mathrm{kg}$. Zooplankton and fish are mobile, and PCBs could have accumulated in their bodies while they were in areas where PCB concentrations in surficial sediment are higher compared with where they were collected, but it is unlikely that the biota collected from the Lake Worth site ever inhabited Woods Inlet or Meandering Road Creek. In lakes and reservoirs, many zooplankton taxa, including the taxa collected for this study, go through a daily cycle of what has been termed "vertical migration," moving to shallow depths at night and to deeper depths during the day to avoid predation (Pennak, 1989). In shallow lakes and reservoirs, zooplankton go through daily horizontal movements swimming towards the open water at dusk and back to the more shallow lake margin during the day to avoid predation (Wojtal and others, 2003). These vertical and horizontal movements should not result in large (several kilometers) dispersals of an individual zooplankton during its life cycle. Largemouth bass, four other centrarchid (sunfish family) species, and forage fish, including gizzard shad, were relatively immotile compared to flathead catfish, spotted bass, and freshwater drum, based on body burdens of total PCBs in these fishes in relation to distance from a highly localized source of PCBs in lake sediment (Bayne and others, 1996). Total PCB concentrations in the centrarchids and gizzard shad in this study decreased by one-half or more compared with concentrations from the source of PCBs in sediment similar to the difference in total PCB concentrations

Table 2. Sum of 15 polychlorinated biphenyl congeners in aquatic invertebrate and fish composite samples collected in Lake Worth, Woods Inlet, and Meandering Road Creek, Fort Worth, Texas, 2007-08.

[PCB, polychlorinated biphenyl; $\mu \mathrm{g} / \mathrm{kg}$, micrograms per kilogram wet weight; LW, Lake Worth; ND, nondetection; ---, no data; WI, Woods Inlet; MC, Meandering Road Creek]

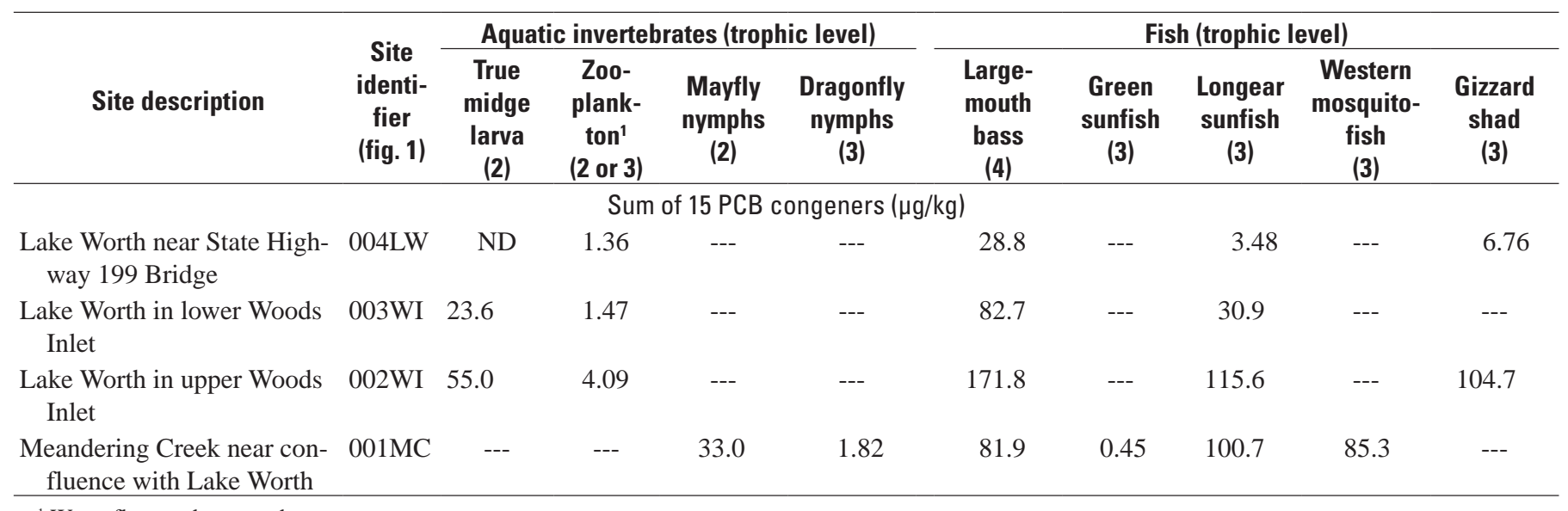

\footnotetext{
${ }^{1}$ Water fleas and copepods.
} 


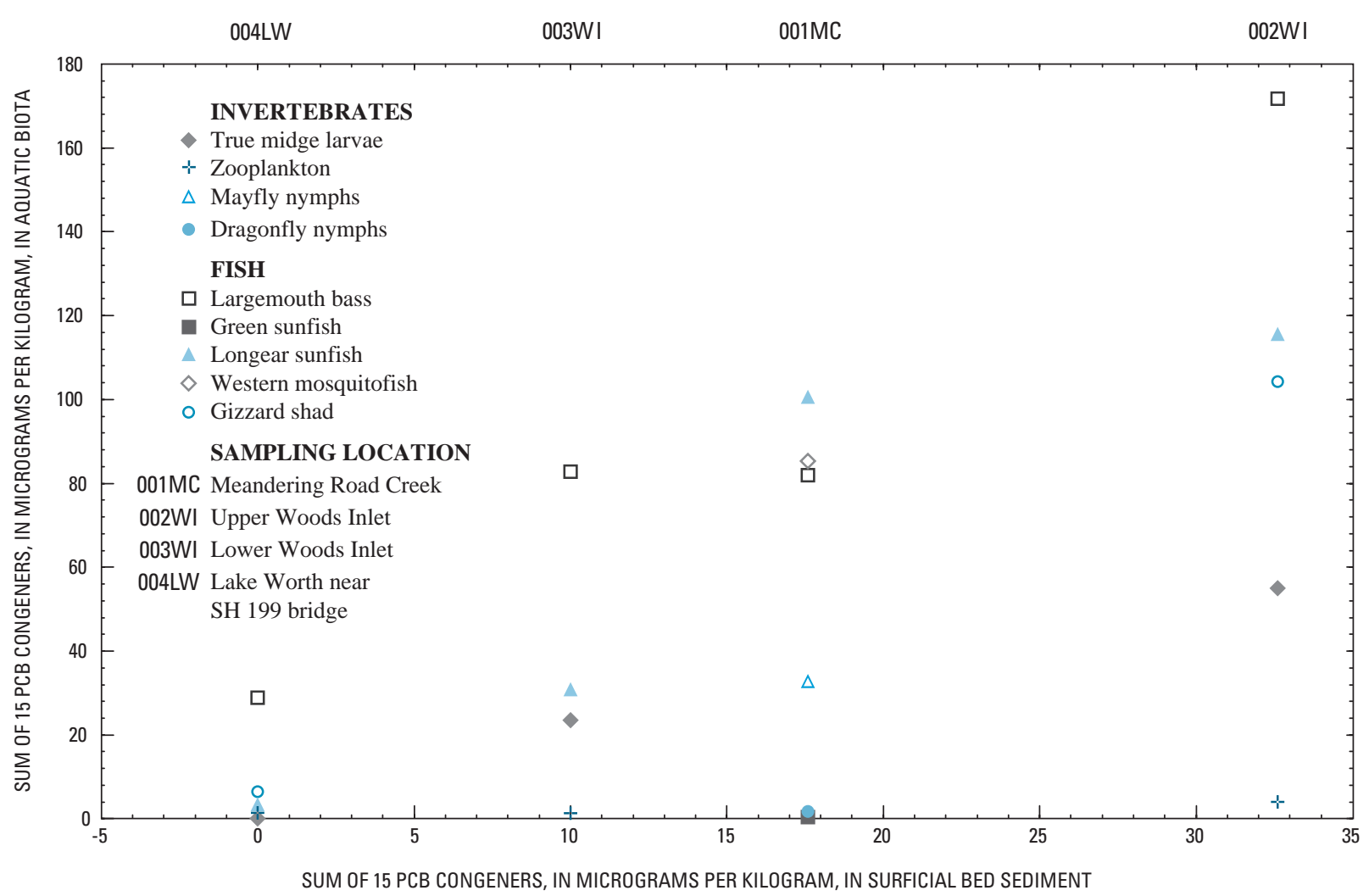

Figure 2. Relation between sum of 15 polychlorinated biphenyl congeners $\left(\sum P C B_{c 15}\right)$ in surficial (top 5 centimeters) bed-sediment samples (Braun and others, 2008) collected in Lake Worth, Woods Inlet, and Meandering Road Creek, 2006, and $\sum \mathrm{PCB}_{\mathrm{c} 15}$ in aquatic invertebrate and fish samples collected in approximately the same locations, 2007-08, Fort Worth, Texas.

(as sum of 15 PCB congeners) in fish between the Lake Worth site and the Upper and Lower Woods Inlet sites (fig. 2); a distance over water of about 10 kilometers.

PCBs were not detected at concentrations greater than or equal to the laboratory minimum reporting level in surficialsediment samples collected in 2000 near the Lake Worth site (Harwell and others, 2003). Harwell and others (2003) determined and quantitated PCBs as Aroclor mixtures 1242, 1254, and 1260 at a laboratory minimum reporting level of $20 \mu \mathrm{g} / \mathrm{kg}$ for each Aroclor; all concentrations were less than $20 \mu \mathrm{g} / \mathrm{kg}$. A lack of detection of PCBs at concentrations equal to or greater than the laboratory minimum reporting level in 2000 near the Lake Worth site might not necessarily indicate a lack of occurrence of PCBs in surficial sediment at this site.

The 15 PCB congeners analyzed for this report are predominately found in Aroclor mixture 1260, and these congeners have a larger number of substituted chlorine atoms compared with congeners generally found in Aroclors 1242 and 1254 (U.S. Environmental Protection Agency, 2008). Congeners with more substituted chlorine atoms have greater hydrophobic and bioavailable properties than congeners with fewer chlorine atoms (Hill and Napolitano, 1997). In 2006, the average $\sum \mathrm{PCB}_{\mathrm{C} 15}$ concentration in surficial sediment was $10 \mu \mathrm{g} / \mathrm{kg}$ in lower Woods Inlet and $33 \mu \mathrm{g} / \mathrm{kg}$ in upper Woods Inlet (fig. 1) (Braun and others, 2008). PCB-congener concentrations measured in surficial-sediment samples collected in 2003 and 2006 from these two sites in Woods Inlet were compared with PCB-congener concentrations measured in biota samples collected from these same locations during 2007-08. The average $\sum \mathrm{PCB}_{\mathrm{C} 15}$ concentration in surficial sediment in Meandering Road Creek in 2006 was $18 \mu \mathrm{g} / \mathrm{kg}$ (fig. 1) (Braun and others, 2008). PCB-congener concentrations measured in streambed-sediment samples collected in 2006 from 11 sites in Meandering Road Creek (Braun and others, 2008) were compared with PCB-congener concentrations measured in biota samples collected from the reach of Meandering Road Creek investigated during this study.

The Spearman rank correlation was used to evaluate the relation between $\Sigma \mathrm{PCB}_{\mathrm{C} 15}$ in surficial sediment collected in 2006 and $\sum \mathrm{PCB}_{\mathrm{C} 15}$ in aquatic invertebrates and fish collected in 2007-08 from the Lake Worth, upper and lower Woods Inlet, and Meandering Road Creek sites. P-values (p) corresponding to each Spearman rank rho value were calculated to evaluate the probability of obtaining the computed test statistic, or one even less likely, when the null hypothesis of no relation between these variables is true (Helsel and Hirsch, 2002). A p-value less than or equal to .05 indicates a statistically significant correlation, and the strength of the correlation increases as the rho value approaches 1 . 
By using the Spearman rank correlation, a statistically significant correlation was found between the $\Sigma \mathrm{PCB}_{\mathrm{C} 15}$ concentration in surficial sediment and the $\sum \mathrm{PCB}_{\mathrm{C} 15}$ concentration in invertebrates and fish from the Lake Worth, upper and lower Woods Inlet, and Meandering Road Creek sites $(\mathrm{rho}=.65, \mathrm{p}=.002)$. This correlation indicates bioaccumulation is likely occurring at multiple trophic levels within Woods Inlet and Meandering Road Creek and that the fish and invertebrates from each site have inhabited the area in and around each site with a trophic link to PCBs in the bed sediment. The sample-collection sites in Woods Inlet are only about 0.5 kilometer apart. Although Meandering Road Creek drains into Woods Inlet by a series of culverts, the mayfly nymphs (and possibly other invertebrates and fish collected in the creek) likely reside in the creek over their life cycle and likely do not move into Woods Inlet. The mayfly nymphs of the family Caenidae that were collected in Meandering Road Creek are shallow lotic (stream-dwelling) organisms (Merritt and Cummins, 1996) and generally would not be found in the deeper lentic (lake- or reservoir-dwelling) habitat of Woods Inlet.

Of the 15 PCB congeners analyzed in invertebrates and fish from the Lake Worth, upper and lower Woods inlet, and Meandering Road Creek sites, 3 were penta-, 4 were hexa-, 6 were hepta-, 1 was octa-, and 1 was a nona-chlorinated PCB congener (appendix 3). Penta- and hexa-chlorinated PCB congeners often account for more than 50 percent of total PCB concentrations in aquatic food webs (Russ and others, 2002). In zooplankton, fish, and surficial-sediment samples from the Lake Worth site and in all invertebrates from the upper and lower Woods Inlet and Meandering Road Creek sites, the same penta- and hexa-chlorinated PCB congeners (congeners 101, 110, 118, 138, 146, 149, and 151) were among the most prevalently detected PCB congeners, indicating a close source linkage between these PCB congeners in sediment and in invertebrates and fish from multiple trophic levels represented at each site.

At the Meandering Road Creek site, the highest PCB concentrations were measured for PCB congeners 138, 110, and 149 (in that order) in mayfly nymph samples (appendix 3), the selected primary consumer for the creek. The highest concentration of PCB congener 110 was measured in largemouth bass samples collected at the Meandering Road Creek site. The highest concentrations were most frequently measured for PCB congeners 138, 110, and 149 (in that order) in multiple surficial bed-sediment samples collected from Meandering Road Creek (Braun and others, 2008, appendix 2).

Among the 15 PCB congeners measured in surficial bed-sediment samples collected from the upper Woods Inlet site, the second and third highest concentrations were measured for congeners 110 and 101, respectively (Braun and others, 2008). PCB congeners 110 and 101 were ranked first and second in concentration, respectively, after congener 149 in samples of midge larvae, the primary consumer from the upper Woods Inlet site. The PCB congeners 110 and 101 were ranked second and third in concentration in largemouth bass samples collected from the lower Woods Inlet site (appendix 3).

\section{Observations about Nitrogen and Carbon Isotope Composition in Relation to Trophic Structure and Bioaccumulation Patterns}

\section{Trophic Levels and Stable Isotope Composition}

Attempts to measure trophic positions on the basis of stable nitrogen enrichment (Post, 2002) were not successful because of difficulties identifying the correct primary consumers. For example, on the basis of $\delta^{13} \mathrm{C}$ results for the Lake Worth and upper and lower Woods Inlet sites (fig. 3), midge larvae consume different carbon sources compared with other invertebrates and fish and thus do not represent a good primary consumer for these sites (fig. 3). Mayfly nymphs were considered the best available taxon to represent the primary consumers at the Meandering Road Creek site; however, on the basis of $\delta^{13} \mathrm{C}$ results, other taxa, such as midge larvae and freshwater snails, might have better represented the primary consumers (had they been available to sample), resulting in reliable trophic position values.

Because trophic positions (nonwhole numbers) either could not be measured or could not be measured reliably, each taxon was assigned a literature-derived trophic level (a whole number from 2 through 4) (table 3 ) to make observations about isotope composition in relation to trophic levels. No primary producers (trophic level 1; phytoplankton or aquatic plants) were collected. Trophic levels were assigned on the basis of food habits for aquatic insect taxa (Merritt and Cummins, 1996), zooplankton taxa (Barnes, 1968), and freshwater fish species in Texas (Thomas and others, 2007). Zooplankton were assigned a trophic level of 3 instead of 2 (table 3) if predatory copepods were more than 50 percent of the zooplankton collected from the site because a predominance of predatory copepods is indicative of tertiary rather than secondary consumers. Predatory copepods are intensive, selective predators and can regulate the structure of zooplankton prey assemblages (Williamson and Reid, 2001).

\section{Horizontal Food Web Position and Stable Isotope Composition}

The horizontal position of biota in a food web is a reflection of their habitat as well as the energy and nutrient sources in their habitat. Differences in horizontal food web position are often denoted by dietary shifts between prey items occupying similar trophic positions (levels) but living in different 


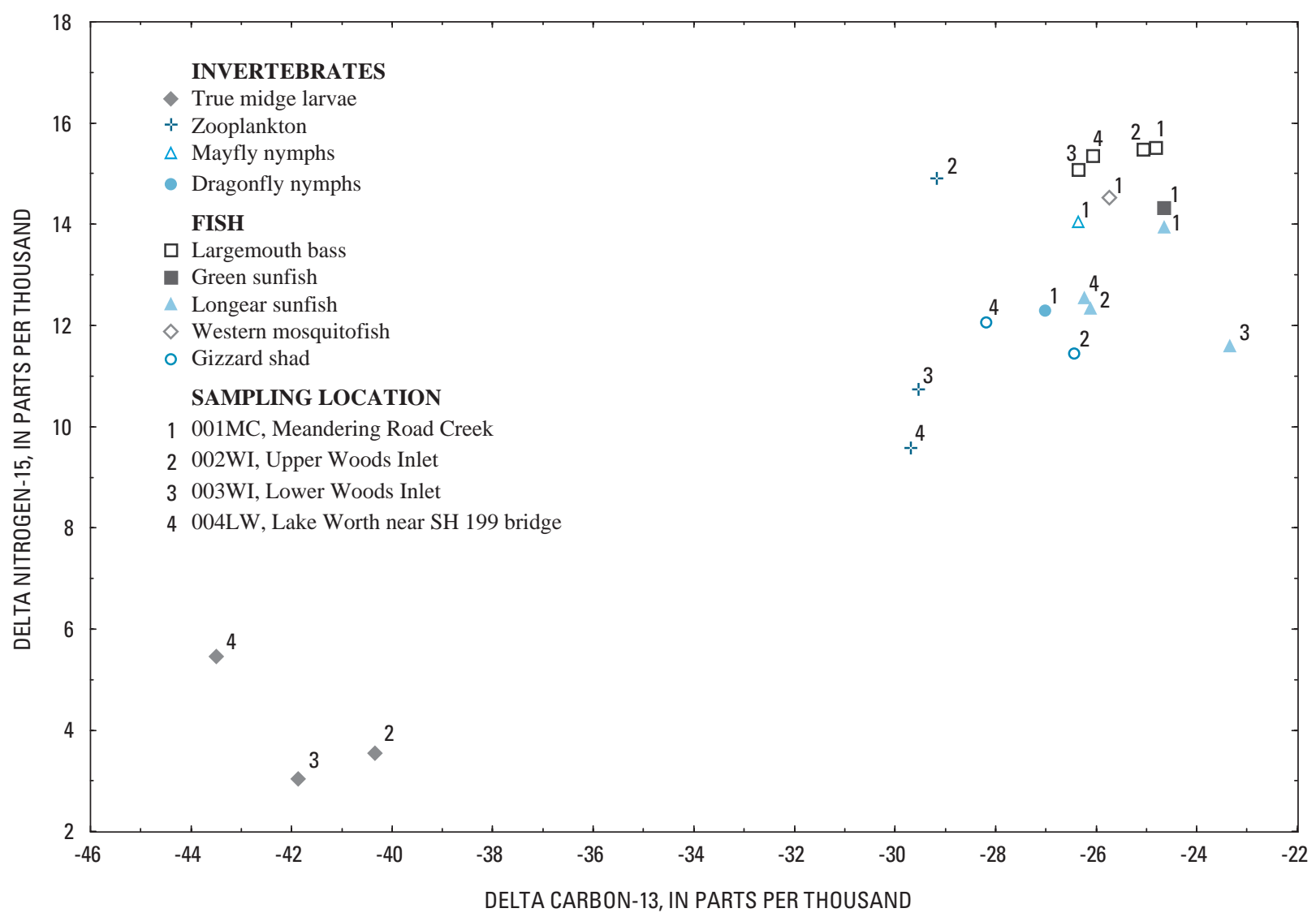

Figure 3. Relation between delta nitrogen-15 $\left(\delta^{15} \mathrm{~N}\right)$ and delta carbon-13 $\left(\delta^{13} \mathrm{C}\right)$ in aquatic invertebrate and fish composite samples collected in Lake Worth, Woods Inlet, and Meandering Road Creek, Fort Worth Texas, 2007-08.

habitats (Lindqvist, 1991). $\delta^{13} \mathrm{C}$ (unlike $\delta^{15} \mathrm{~N}$ ) is conserved through multiple trophic levels in an ecosystem and can be used to determine the primary source of carbon for the base of the food chain, as well as the horizontal food web position of biota in an ecosystem (Kidd, 1998). Because there is little change in $\delta^{13} \mathrm{C}$ as carbon is obtained by an organism through its diet, $\delta^{13} \mathrm{C}$ can be used to trace carbon and energy flow from primary producers to tertiary consumers (Kidd and others, 2001). Additional uses of $\delta^{13} \mathrm{C}$ include differentiating between a benthic and a pelagic source of carbon, and defining or confirming the principal trophic pathway of energy and bioavailable contaminants (Kidd, 1998) in an ecosystem. For this analysis, the primary uses of $\delta^{13} \mathrm{C}$ were to define the horizontal position of selected taxa to help determine if they were good candidates as primary consumers.

The $\delta^{13} \mathrm{C}$ for midge larvae collected at the Lake Worth and upper and lower Woods Inlet sites were more negative compared with the $\delta^{13} \mathrm{C}$ of all other taxa, indicating midge larvae were more depleted of ${ }^{13} \mathrm{C}$ compared with all other sampled aquatic invertebrates and fish. The relative depletion of ${ }^{13} \mathrm{C}$ in the midge larvae (fig. 3; table 3 ) might indicate this taxon obtains most of its carbon from dietary sources different than those for all other sampled invertebrates and fish (Kidd, 1998; Bastviken and others, 2003). The $\delta^{13} \mathrm{C}$ for all other taxa were less negative (less depleted) compared with the $\delta^{13} \mathrm{C}$ for midge larvae. The midge larvae were collected in surficial sediment from 1 to 5 meters deep, and as detritivores, the principal carbon source for this taxon might be phytoplankton detritus, benthic algae, or both. The majority of other invertebrate and fish taxa were collected in more shallow zones in the lake, inlet, and creek, generally less than 2 meters deep, that were most likely dominated by carbon sourced from benthicdwelling periphyton and benthic detritus.

\section{Enrichment of Nitrogen-15 and Trophic Structure of Aquatic Invertebrates and Fish}

Kidd (1998, p. 357) describes how nitrogen and carbon isotopes fractionate in a predictable manner from prey to predator and provide a continuous, relative measure of an organism's trophic positioning. As predators feed on other organisms, the predator preferentially excretes the lighter nitrogen isotope ${ }^{14} \mathrm{~N}$ and thereby becomes more enriched in the heavier nitrogen isotope ${ }^{15} \mathrm{~N}$ than its prey (Steele and Daniel, 1978; Vander Zanden and Rasmussen, 2001). An increase in the ratio of the heavier isotope $\left({ }^{15} \mathrm{~N}\right)$ to the lighter isotope $\left({ }^{14} \mathrm{~N}\right)$ in an organism, referred to as enrichment of 
Table 3. Nitrogen and carbon isotope enrichment in and assigned trophic level for aquatic invertebrate and fish composite samples collected in Lake Worth, Woods Inlet, and Meandering Road Creek, Fort Worth, Texas, 2007-08.

$\left[\delta^{15} \mathrm{~N}\right.$, delta nitrogen-15; \%o, per mil; TL; assigned trophic level; $\delta^{13} \mathrm{C}$, delta carbon-13; LW, Lake Worth; ---, no data; WI, Woods Inlet; MC, Meandering Road Creek]

\begin{tabular}{|c|c|c|c|c|c|c|c|c|c|c|c|}
\hline \multirow[b]{2}{*}{ Site description } & \multirow[b]{2}{*}{$\begin{array}{c}\text { Site } \\
\text { identifier } \\
\text { (fig. 1) }\end{array}$} & \multicolumn{10}{|c|}{ Aquatic invertebrates } \\
\hline & & $\begin{array}{c}\delta^{15} \mathrm{~N} \\
\% 0 \\
{[\mathrm{TL}]}\end{array}$ & $\begin{aligned} \delta^{1} \\
\%\end{aligned}$ & & $\begin{array}{c}\delta^{15} \mathrm{~N}, \\
\% \% \\
\text { (percent } \\
\text { predatory } \\
\text { opepods) } \\
\text { [TL] }\end{array}$ & $\begin{array}{c}\delta^{13} \mathbf{C} \\
\%\end{array}$ & $\begin{array}{c}\delta^{15} \mathbf{N}, \\
\% 0 \\
{[T L]}\end{array}$ & \multicolumn{2}{|c|}{$\begin{array}{c}\delta^{13} \mathbf{C} \\
\%\end{array}$} & $\begin{array}{c}\delta^{15} \mathrm{~N}, \\
\% \\
{[\mathrm{TL}]}\end{array}$ & $\begin{array}{c}\delta^{13} \mathbf{C} \\
\% 0\end{array}$ \\
\hline Lake Worth near State Highway 199 Bridge & 004LW & $\begin{array}{r}5.46 \\
{[2]}\end{array}$ & -43 & & $\begin{array}{c}9.56 \\
(25) \\
{[2 \text { or } 3]}\end{array}$ & -29.68 & --- & \multicolumn{2}{|c|}{---} & --- & --- \\
\hline Lake Worth in lower Woods Inlet & 003WI & $\begin{array}{r}3.04 \\
{[2]}\end{array}$ & -41 & & $\begin{array}{c}10.73 \\
(43) \\
{[2 \text { or } 3]}\end{array}$ & -29.43 & --- & \multicolumn{2}{|c|}{---} & --- & --- \\
\hline $\begin{array}{l}\text { Meandering Road Creek near confluence } \\
\text { with Lake Worth }\end{array}$ & $001 \mathrm{MC}$ & --- & - & & --- & --- & $\begin{array}{c}14.05 \\
{[2]}\end{array}$ & \multicolumn{2}{|c|}{-26.36} & $\begin{array}{c}13.66 \\
{[3]}\end{array}$ & -27.01 \\
\hline \multirow{3}{*}{ Site description } & \multirow{3}{*}{$\begin{array}{c}\text { Site } \\
\text { identifier } \\
\text { (fig. 1) }\end{array}$} & \multicolumn{10}{|c|}{ Fish } \\
\hline & & \multicolumn{2}{|c|}{$\begin{array}{l}\text { Largemouth } \\
\text { bass }\end{array}$} & \multicolumn{2}{|c|}{$\begin{array}{l}\text { Green } \\
\text { sunfish }\end{array}$} & \multicolumn{2}{|c|}{$\begin{array}{c}\text { Longear } \\
\text { sunfish }\end{array}$} & \multicolumn{2}{|c|}{$\begin{array}{c}\text { Western } \\
\text { mosquitofish }\end{array}$} & \multicolumn{2}{|c|}{$\begin{array}{l}\text { Gizzard } \\
\text { shad }\end{array}$} \\
\hline & & $\begin{array}{c}\delta^{15} \mathbf{N}, \\
\% \\
{[\mathrm{TL}]}\end{array}$ & $\begin{array}{c}\delta^{13} \mathbf{C} \\
\% 0\end{array}$ & $\begin{array}{c}\delta^{15} \mathrm{~N}, \\
\% 0 \\
{[\mathrm{TL}]}\end{array}$ & $\begin{array}{c}\delta^{13} \mathbf{C} \\
\% 0\end{array}$ & $\begin{array}{c}\delta^{15} \mathbf{N}, \\
\% \\
{[\mathrm{TL}]}\end{array}$ & $\begin{array}{c}\delta^{13} \mathbf{C} \\
\%\end{array}$ & $\begin{array}{c}\delta^{15} \mathrm{~N}, \% 0 \\
{[\mathrm{TL}]}\end{array}$ & $\begin{array}{c}\delta^{13} \mathbf{C} \\
\%\end{array}$ & $\begin{array}{c}\delta^{15} \mathbf{N}, \\
\% 0 \\
{[\mathrm{TL}]}\end{array}$ & $\begin{array}{c}\delta^{13} \mathbf{C} \\
\% 0\end{array}$ \\
\hline $\begin{array}{l}\text { Meandering Road Creek near confluence } \\
\text { with Lake Worth }\end{array}$ & $001 \mathrm{MC}$ & $\begin{array}{c}15.51 \\
{[4]}\end{array}$ & -24.83 & $\begin{array}{c}14.32 \\
{[3]}\end{array}$ & -24.65 & $\begin{array}{c}13.93 \\
{[3]}\end{array}$ & -24.65 & $\begin{array}{c}14.53 \\
{[3]}\end{array}$ & -25.74 & --- & --- \\
\hline
\end{tabular}

${ }^{1}$ Water fleas and copepods.

${ }^{15} \mathrm{~N}$ (Minagawa and Wada, 1984), was highest in largemouth bass (trophic level 4) at all sites and lowest for midge larvae (trophic level 2) that inhabit surficial sediment at the Lake Worth and upper and lower Woods Inlet sites (table 3). $\delta^{15} \mathrm{~N}$ ranged from a maximum of $15.51 \%$ for largemouth bass at the Meandering Road Creek site to a minimum of $3.04 \%$ for midge larvae at the lower Woods Inlet site. Intermediate $\delta^{15} \mathrm{~N}$ values (between the $\delta^{15} \mathrm{~N}$ values measured in midge larvae and largemouth bass samples) were measured in samples of green sunfish, longear sunfish, western mosquitofish, and gizzard shad (all trophic level 3). The highest $\delta^{15} \mathrm{~N}$ value measured in zooplankton (trophic level 2 or 3, depending on species composition) samples was $14.90 \%$ at the upper Woods Inlet site. $\delta^{15} \mathrm{~N}$ values of 14.05 and $13.66 \%$ were measured in samples of mayfly nymphs (trophic level 2) and dragonfly nymphs (trophic level 3), respectively, at the Meandering Road Creek site. The $\delta^{15} \mathrm{~N}$ values measured in samples of mayfly nymphs and dragonfly nymphs were similar to the $\delta^{15} \mathrm{~N}$ values measured in the majority of samples of fish taxa at all four sites, which ranged from $11.47 \%$ o for gizzard shad to $15.51 \%$ 
for largemouth bass. $\delta^{15} \mathrm{~N}$ values measured in zooplankton samples collected at the Lake Worth and lower Woods Inlet sites were 9.56 and $10.73 \%$, respectively, which were lower than the $\delta^{15} \mathrm{~N}$ values measured for most of the fish taxa. $\delta^{15} \mathrm{~N}$ values measured in midge larvae samples ranged from 3.04 to $5.46 \%$ or the Lake Worth and upper and lower Woods Inlet sites and were lower than the $\delta^{15} \mathrm{~N}$ values measured in all other aquatic invertebrates and fish samples. The $\delta^{15} \mathrm{~N}$ values for largemouth bass samples from the Lake Worth and upper and lower Woods Inlet sites were consistently higher than $\delta^{15} \mathrm{~N}$ values for the aquatic invertebrates. $\delta^{15} \mathrm{~N}$ generally increased as trophic level increased. The enrichment of the heavier isotope ${ }^{15} \mathrm{~N}$ from prey to predator (usually $3-5 \%$ ) provides a continuous variable that can be used to gain insights into the biomagnification of organochlorines, such as PCBs, in an aquatic food web (Kidd and others, 2001).

The range in $\delta^{15} \mathrm{~N}$ values was smaller for higher trophic level organisms such as largemouth bass and the other fish taxa compared with the range in $\delta^{15} \mathrm{~N}$ values for the aquatic invertebrate taxa (table 3). For example, the range in $\delta^{15} \mathrm{~N}$ values measured in largemouth bass was $0.44 \%$ compared with $5.34 \%$ o for zooplankton. Greater variation in $\delta^{15} \mathrm{~N}$ is expected in primary consumers, such as midge larvae and zooplankton, compared with tertiary consumers, such as largemouth bass and other fish, because the invertebrates are shorter lived, and $\delta^{15} \mathrm{~N}$ in the invertebrates more closely reflects the temporal and spatial variability in the concentration of stable nitrogen isotopes in short-lived primary producers (Vander Zanden and Rasmussen, 1999; Post, 2002). Zooplankton were collected about 6 months later than the other taxa collected from the Lake Worth and Woods Inlet sites (April 2008 compared with September 2007), and seasonal and intergenerational differences in concentrations of stable isotopes were not accounted for in this study. Dragonfly nymphs from the Meandering Road Creek site are predators and secondary consumers (trophic level 3); $\delta^{15} \mathrm{~N}$ for this taxon (13.66\%o) was expected to be higher than $\delta^{15} \mathrm{~N}$ for mayfly nymphs $(14.05 \%$ ), a primary consumer (trophic level 2 ) at this site, and lower than the $\delta^{15} \mathrm{~N}$ for tertiary consumers (11.47 to $15.51 \%$, trophic level 3 or 4 , depending on fish species).

\section{Nitrogen Isotope Enrichment and Polychlorinated Biphenyl Concentrations in Aquatic Invertebrates and Fish}

Because trophic levels are an indication of expected biomagnification in a food web, they can be used to make observations regarding patterns of bioaccumulation (Broman and others, 1992; Rolff and others, 1993). At the Lake Worth and upper and lower Woods Inlet sites, the $\sum \mathrm{PCB}_{\mathrm{C} 15}$ concentration increases with nitrogen enrichment (as indicated by $\delta^{15} \mathrm{~N}$ ) in accordance with trophic level, from aquatic invertebrates to fish, with the highest $\sum \mathrm{PCB}_{\mathrm{C} 15}$ concentrations and $\delta^{15} \mathrm{~N}$ values measured in largemouth bass (figs. 4 and 5).

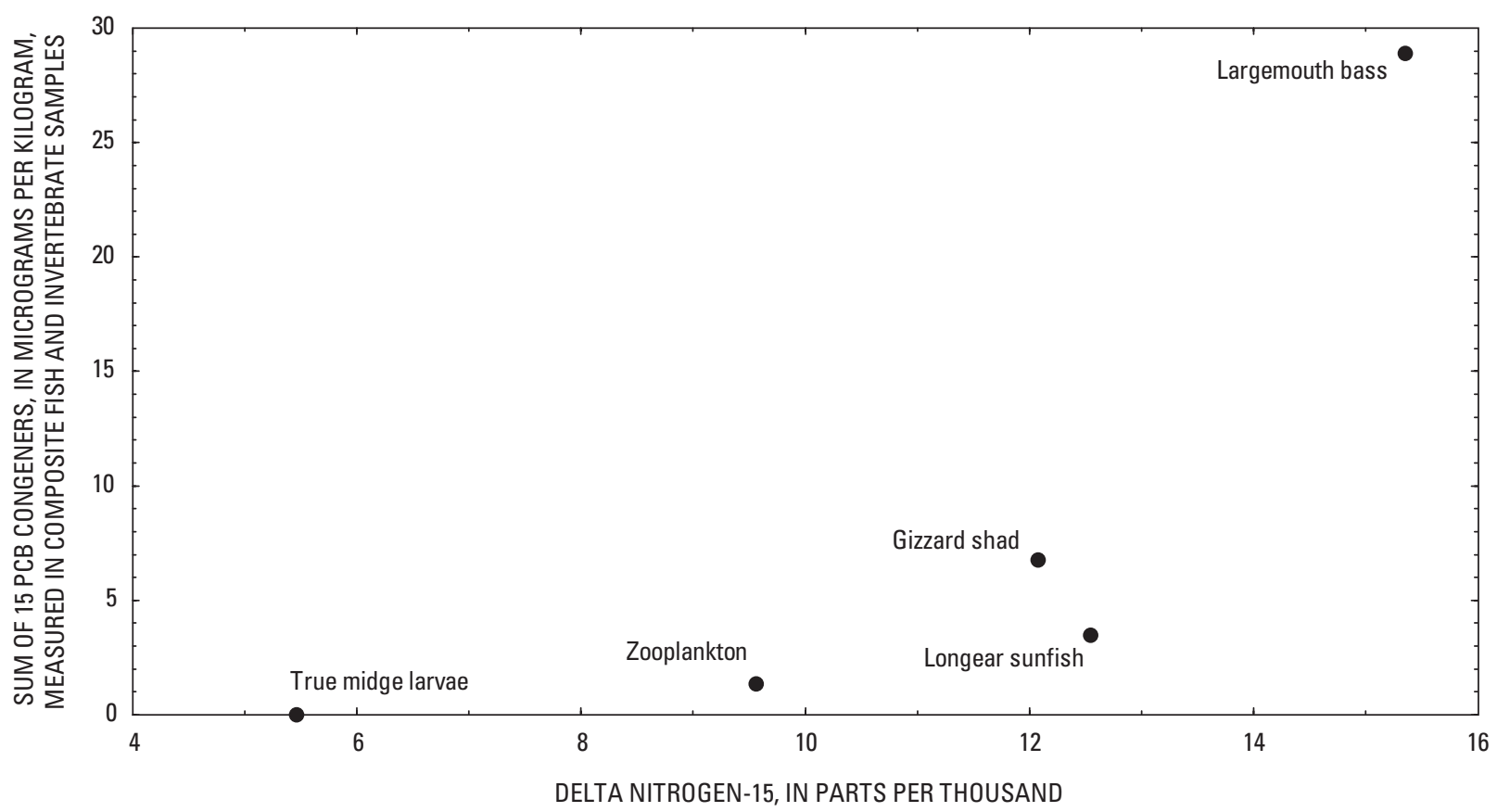

Figure 4. Sum of 15 polychlorinated biphenyl congeners $\left(\sum P C B_{c 15}\right)$ compared with amount of nitrogen enrichment (represented by an increase in ratio of nitrogen-15 to nitrogen-14 [ $\left.\delta^{15} \mathrm{~N}\right]$ ) in aquatic invertebrate and fish composite samples collected at reference site Lake Worth near State Highway 199 Bridge (004LW), Fort Worth, Texas, 2007-08. 


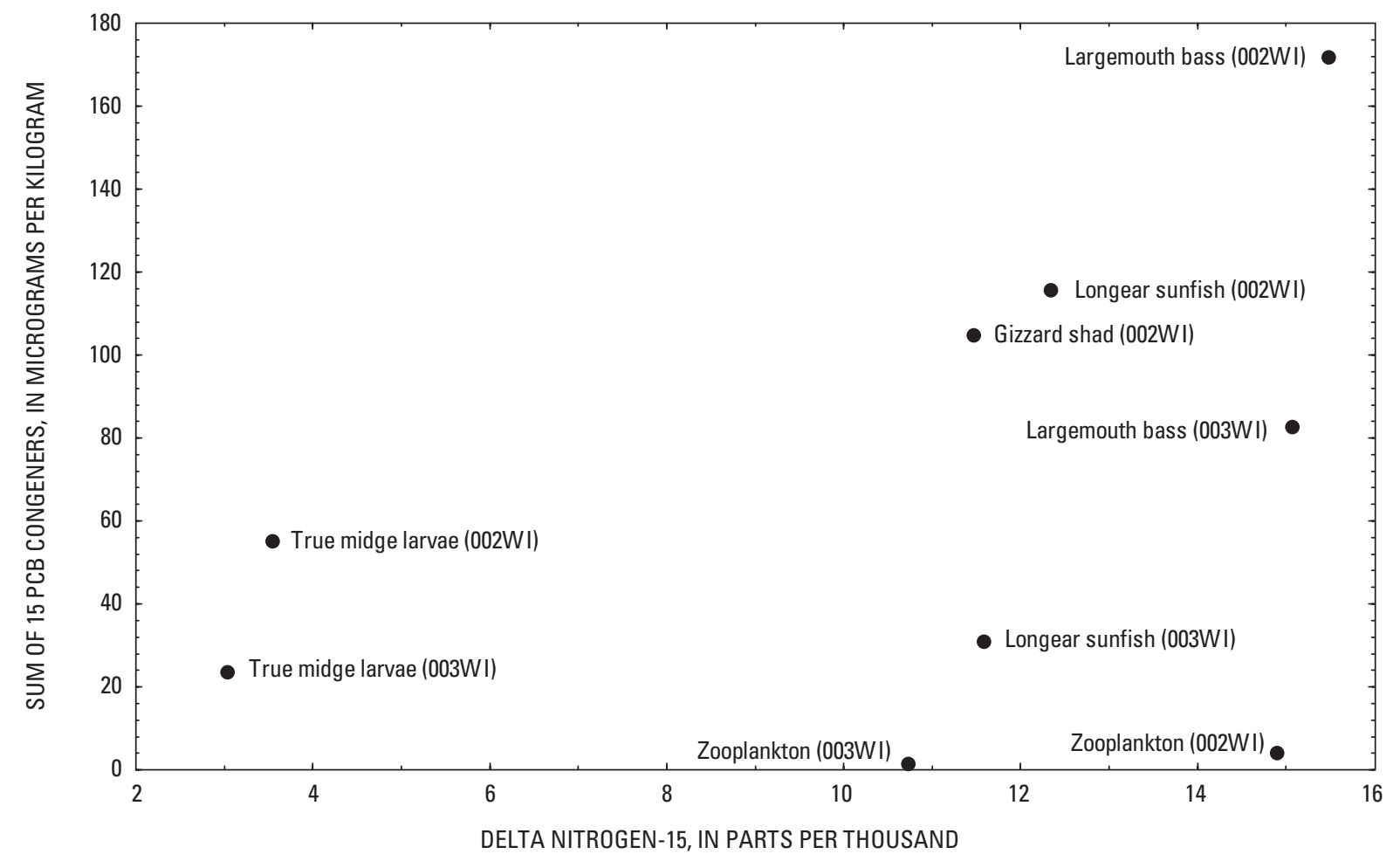

Figure 5. Sum of 15 polychlorinated biphenyl congeners $\left(\sum P C B_{c 15}\right)$ compared with amount of nitrogen enrichment (represented by an increase in ratio of nitrogen-15 to nitrogen-14 [ $\left.\left.\delta^{15} \mathrm{~N}\right]\right)$ in aquatic invertebrate and fish composite samples collected at Lake Worth in upper and lower Woods Inlet (sites 002WI and 003WI), Fort Worth, Texas, 2007-08.

Zooplankton (trophic level 2 or 3, depending on taxa composition) had relatively high $\delta^{15} \mathrm{~N}$ values but low $\sum \mathrm{PCB}_{\mathrm{C} 15}$ concentrations compared with other invertebrate and vertebrate taxa. In zooplankton, the $\sum \mathrm{PCB}_{\mathrm{C} 15}$ concentration was highest $(4.09 \mu \mathrm{g} / \mathrm{kg})$ at the upper Woods Inlet site (table 2) where previous USGS studies indicated PCB concentrations in surficial sediment were highest. The number of zooplankton and associated sediment samples $(\mathrm{n}=3$ for each) were insufficient to statistically evaluate the relation between the concentration of $\sum \mathrm{PCB}_{\mathrm{C} 15}$ in zooplankton from the Lake Worth and Woods Inlet sites and the concentration of $\sum \mathrm{PCB}_{\mathrm{C} 15}$ in surficial sediment measured at these sites in previous studies (fig. 2). Zooplankton collected in this study feed on pelagicdwelling phytoplankton or other zooplankton (Kling and others, 1992) and generally are not in physical contact with surficial sediment. The relatively high $\delta^{15} \mathrm{~N}$ (table 3 ) but low $\sum \mathrm{PCB}_{\mathrm{C} 15}$ concentration (table 2) in the zooplankton samples from the Lake Worth and Woods Inlet sites might indicate that zooplankton occupy multiple trophic levels (Sprules and Bowerman, 1988). It also might indicate less bioavailability (degree to which a chemical can be taken up by biota) of PCBs from the water column where zooplankton feed compared with the bioavailability of PCBs from sediment where benthic organisms feed, or that PCB concentrations in pelagic food sources are lower compared with those in benthic food sources. Predatory copepods accounted for 25 to 78 percent of the relative abundance of all zooplankton taxa at the Lake Worth and Woods Inlet sites (table 3). A decrease in $\delta^{15} \mathrm{~N}$ in zooplankton samples collected from the upper Woods Inlet, lower Woods Inlet, and Lake Worth sites (in that order) corresponds to a decrease in the percentage of predatory copepods present in each zooplankton sample from these sites. The large relative abundance of predatory copepods might explain the relatively high $\delta^{15} \mathrm{~N}$ for zooplankton compared with other taxa, whereas the lack of any trophic connection to surficial sediment would explain the relatively low concentration of the $\sum \mathrm{PCB}_{\mathrm{C} 15}$ for this taxon.

Whereas nitrogen enrichment as $\delta^{15} \mathrm{~N}$ in longear sunfish (trophic level 3) and largemouth bass (tropic level 4) is similar in magnitude, the $\sum \mathrm{PCB}_{\mathrm{C} 15}$ concentration is higher in largemouth bass and longear sunfish from the upper and lower Woods Inlet sites (30.9 to $171.8 \mu \mathrm{g} / \mathrm{kg}$ ) compared with the $\sum \mathrm{PCB}_{\mathrm{C} 15}$ concentration in these fish from the Lake Worth site (3.48 to $28.8 \mu \mathrm{g} / \mathrm{kg}$ ). Because the invertebrate and fish communities at the Woods Inlet and Lake Worth sites are trophically similar, the PCB concentrations measured in longear sunfish and largemouth bass and the biomagnification of PCBs at the higher trophic levels in the Woods Inlet and Lake Worth sites are likely controlled by differences in the concentration of PCBs in surficial sediment. Total PCB concentrations in largemouth bass and other centrarchids (family of sunfishes) was significantly negatively correlated to the distance from a 
source of PCBs in sediment in a lake in Alabama (Bayne and others, 2002), but this was not the case for flathead catfish (Pylodictis olivaris) collected from the same sites. These results provide indirect evidence that PCB residues in fish can be used as an indicator of fish motility where there is a large gradient in PCBs in lake bed sediment.

Nitrogen enrichment as $\delta^{15} \mathrm{~N}$ was more variable in aquatic invertebrates and fish from the Meandering Road Creek site compared with $\delta^{15} \mathrm{~N}$ values measured in these biota samples at the other sites (fig. 6). The $\delta^{15} \mathrm{~N}$ values measured in aquatic invertebrates and fish from the Meandering Road Creek site did not follow expected $\delta^{15} \mathrm{~N}$ levels for each taxon based on what is known about the diet and trophic level of the taxa. For example, $\delta^{15} \mathrm{~N}$ values measured in mayfly nymphs were similar to those measured in longear sunfish and green sunfish, and the $\sum \mathrm{PCB}_{\mathrm{C} 15}$ measured in the mayfly nymphs was about one-half the $\sum \mathrm{PCB}_{\mathrm{C} 15}$ measured in some fish (longear sunfish, western mosquitofish, and largemouth bass) from this site. This similarity in nitrogen enrichment among different trophic levels might be an indication of the open nature of stream ecosystems, compared with lakes, that contributes to larger variability in short- and long-term nitrogen and carbon sources (Vander Zanden and Fetzer, 2007).

The Spearman rank correlation was used to evaluate the relation between $\delta^{15} \mathrm{~N}$ and $\Sigma \mathrm{PCB}_{\mathrm{C} 15}$ in composite samples of different species of invertebrates and fish collected from the various sampling sites in Lake Worth, Woods Inlet, and Meandering Road Creek. At the Lake Worth reference site, where PCB contamination had not been detected previously, there was a statistically significant correlation between nitrogen enrichment (represented by an increase in $\delta^{15} \mathrm{~N}$ ) and $\sum \mathrm{PCB}_{\mathrm{C} 15}$ in aquatic invertebrates and fish collected from the site (rho $=.90, \mathrm{p}=.05)$ (fig. 4). There was not a statistically significant correlation between $\delta^{15} \mathrm{~N}$ and $\sum \mathrm{PCB}_{\mathrm{C} 15}$ in aquatic invertebrates and fish from the Woods Inlet sites (rho $=.50$, $\mathrm{p}=.17$ ) (fig. 5). Removing zooplankton from the analysis of the relation between $\delta^{15} \mathrm{~N}$ and $\Sigma \mathrm{PCB}_{\mathrm{C} 15}$ for the Woods Inlet sites did not improve the correlation results (as pelagic feeders with little contact with surficial sediment, this taxon was not thought to represent an important trophic pathway for the biomagnification of PCBs in the fish of Lake Worth). Nitrogen enrichment, represented by an increase in $\delta^{15} \mathrm{~N}$ in aquatic invertebrates and fish from the Meandering Road Creek site, was not significantly positively correlated ( $\mathrm{rho}=.14, \mathrm{p}=.78$ ) to the concentration of $\sum \mathrm{PCB}_{\mathrm{C} 15}$ in aquatic invertebrates and fish from the site (fig. 6).

Despite visual evidence of a monotonic association (positive correlation) between the $\sum \mathrm{PCB}_{\mathrm{C} 15}$ in biota and the $\sum \mathrm{PCB}_{\mathrm{C} 15}$ in surficial bed sediment (fig. 2), the small sample sizes ( $\mathrm{n}=5$ for the Meandering Road Creek site, $\mathrm{n}=7$ for the Woods Inlet sites, and $\mathrm{n}=5$ for the Lake Worth site) likely contributed to the lack of statistically significant correlations

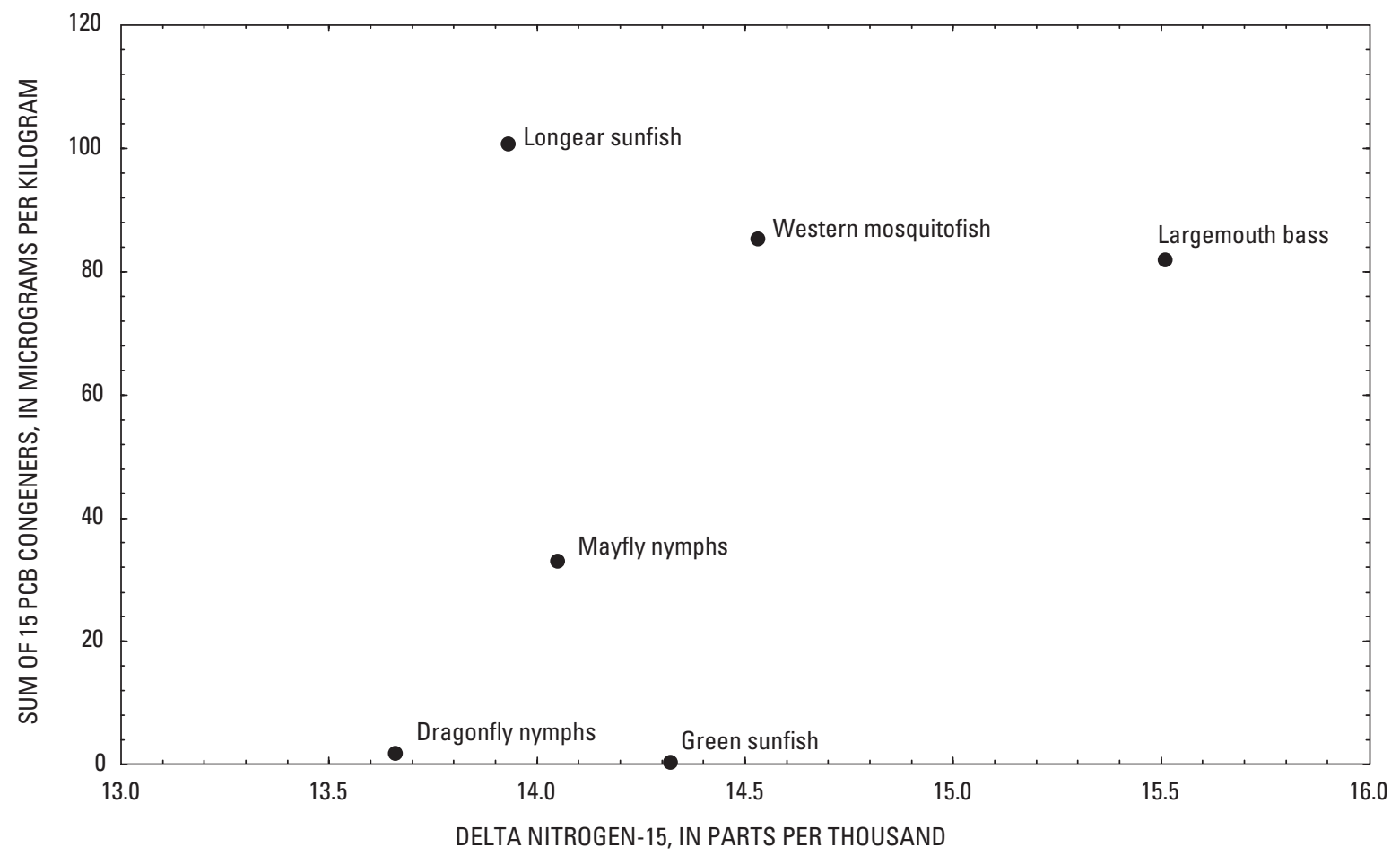

Figure 6. Sum of 15 polychlorinated biphenyl congeners $\left(\sum \mathrm{PCB}_{\mathrm{c15}}\right)$ compared with amount of nitrogen enrichment (represented by an increase in ratio of nitrogen-15 to nitrogen-14 [ $\left.\left.\delta^{15} \mathrm{~N}\right]\right)$ in aquatic invertebrate and fish composite samples collected at Meandering Road Creek (site 001MC), Fort Worth, Texas, 2007-08. 
between the $\delta^{15} \mathrm{~N}$ in biota and the $\sum \mathrm{PCB}_{\mathrm{C} 15}$ in surficial bed sediment (as evidenced by low rho values and high p-values). Stronger statistical correlations between $\delta^{15} \mathrm{~N}$ and the $\sum \mathrm{PCB}_{\mathrm{C} 15}$ concentration in aquatic invertebrates and fish might be obtained by collecting and analyzing individual invertebrates and fish rather than the composite sample data that were obtained in this study, which greatly reduced the sample sizes available for statistical analyses.

\section{Implications for Ecological Processes and Polychlorinated Biphenyl Concentrations in Aquatic Invertebrates and Fish}

The results of this study provide insights on the importance of understanding the intermediate ecological processes between a bioavailable source of PCBs in surficial sediment and the transfer of these contaminants through the aquatic food chain, ultimately to a top-tier tertiary consumer, such as largemouth bass. The results of this study provide evidence for the variability in nitrogen and carbon enrichment and corresponding PCB concentrations measured in whole tissue samples of taxa, such as largemouth bass, from different sites and among different taxa from the same site, more so for the invertebrates and fish from the Meandering Road Creek site compared with those from the Lake Worth and upper and lower Woods Inlet sites. Variability in PCBs concentration in surficial sediment at the Lake Worth, upper and lower Woods Inlet, and Meandering Road Creek sites affects the bioavailability and ultimately the PCB concentrations in the aquatic invertebrates and fish that reside at each of these sites. In addition to PCB concentrations in sediment, variability in nitrogen enrichment at the various trophic levels and differences among the types of aquatic invertebrate and fish at each site affected the bioavailability and biomagnification of PCBs.

Much of the emphasis, to date, in PCB-related aquatic studies in Texas reservoirs has been concerned with the occurrence and concentration of these contaminants in sediment (Harwell and others, 2003; Braun and others, 2008) or in fish commonly caught and consumed by the public (Texas Department of State Health Services, 2007). The results of this study provide supporting information that can assist regulators in the risk assessment process by highlighting the variable nature of PCB accumulation in aquatic invertebrates and fish, even in a relatively small aquatic ecosystem, such as the study area investigated for this report.

\section{Summary}

During 2007-08 the U.S. Geological Survey (USGS), in cooperation with the U.S. Air Force, evaluated the concentration of polychlorinated biphenyls (PCBs) in aquatic invertebrates and fish (biota) collected from one site in the main body of Lake Worth (004LW), two sites in a small inlet in Lake Worth (lower Woods Inlet [002WI] and upper Woods Inlet [003WI]), and one site in Meandering Road Creek $(004 \mathrm{LW})$ in Fort Worth, Texas. Aquatic invertebrates and fish (biota samples) collected at each site included taxa representing primary, secondary, and tertiary consumers. Biota samples were composited, freeze-dried, ground, and analyzed for 15 PCB congeners and stable isotopes of nitrogen (nitrogen-15 $\left[{ }^{15} \mathrm{~N}\right]$ and nitrogen-14 $[14 \mathrm{~N}]$ ) and carbon (carbon-13 $\left[{ }^{13} \mathrm{C}\right]$ and carbon-12 [ $\left.{ }^{12} \mathrm{C}\right]$ ).

PCB concentrations measured in the biota samples during this study were compared with PCB concentrations measured in sediment samples obtained from approximately the same sampling locations during previous USGS studies of Lake Worth and Meandering Road Creek. Additionally, differences in the amounts of ${ }^{15} \mathrm{~N}$ compared to ${ }^{14} \mathrm{~N}$ (expressed as $\delta^{15} \mathrm{~N}$ ) and ${ }^{13} \mathrm{C}$ to ${ }^{12} \mathrm{C}$ (expressed as $\delta^{13} \mathrm{C}$ ) in biota samples were assessed by species and sampling location and compared to $\mathrm{PCB}$ concentrations in biota samples to make observations about trophic structure and patterns of bioaccumulation.

The Lake Worth (reference) site is near the State Highway 199 bridge, and two sites are in Woods Inlet (upper and lower), which receives runoff from Meandering Road Creek. The fourth site is in Meandering Road Creek near the confluence with Lake Worth and upstream of Woods Inlet. PCB-contaminated runoff has historically drained from Air Force Plant 4 to Meandering Road Creek, which flows into Woods Inlet of Lake Worth. The four sites were selected because they represent the range in PCB-congener concentrations measured in surficial sediment in Lake Worth, Woods Inlet, and Meandering Road Creek during previous USGS studies and, thus, the likely range in the bioavailability and biomagnification of PCBs in aquatic invertebrates and fish.

Aquatic invertebrate and fish taxa collected at the Lake Worth, upper and lower Woods Inlet, and Meandering Road Creek sites were chosen to represent the types of predator and prey trophic interactions expected to contribute to the biomagnification of PCBs. Aquatic invertebrates targeted for collection at the Lake Worth and upper and lower Woods Inlet sites included true midge larvae, zooplankton, mayfly nymphs, and dragonfly nymphs and the fish taxa targeted for collection at these sites included largemouth bass, longear sunfish, and gizzard shad. Fish targeted for collection at the Meandering Road Creek site included longear sunfish and largemouth bass; western mosquitofish and green sunfish were also collected to better represent the different types of fish and thus better represent the trophic structure at the site. Primary consumers, such as true midge larvae, zooplankton, and mayfly nymphs, are the essential trophic pathway for the biomagnification of PCBs from surficial sediment and the water column to secondary consumers, such as dragonfly nymphs, and tertiary consumers, such as largemouth bass and other fish taxa.

The sum of the concentration of 15 PCB congeners $\left(\sum \mathrm{PCB}_{\mathrm{C} 15}\right)$ was highest in largemouth bass from the upper Woods Inlet site $(171.8 \mu \mathrm{g} / \mathrm{kg})$; PCBs were not detected in 
true midge larvae at the Lake Worth site. $\sum \mathrm{PCB}_{\mathrm{C} 15}$ in true midge larvae at the upper Woods Inlet site $(55.0 \mu \mathrm{g} / \mathrm{kg})$ was more than 2 times as high as that at the lower Woods Inlet site $(23.6 \mu \mathrm{g} / \mathrm{kg})$, and about as much as an order of magnitude higher compared with $\sum \mathrm{PCB}_{\mathrm{C} 15}$ in zooplankton at the Lake Worth and upper and lower Woods Inlet sites, which ranged from 1.36 to $4.09 \mu \mathrm{g} / \mathrm{kg}$. $\sum \mathrm{PCB}_{\mathrm{C} 15}$ was highest in fish taxa at the upper Woods Inlet site, and lowest in all taxa at the Lake Worth site. PCBs were detected in largemouth bass, longear sunfish, gizzard shad, and zooplankton at the Lake Worth site, even though PCBs were not detected in the surficialsediment samples collected previously from the site. Using the Spearman rank correlation, a statistically significant correlation was found between $\sum \mathrm{PCB}_{\mathrm{C} 15}$ concentrations in surficial sediment and in invertebrates and fish from the Lake Worth, upper and lower Woods Inlet, and Meandering Road Creek sites $(\mathrm{rho}=.65, \mathrm{p}=.002)$. This correlation indicates bioaccumulation is likely occurring at multiple trophic levels within Woods Inlet and Meandering Road Creek. The dominant PCB congeners in fish, invertebrate, and surficial-sediment samples from the Lake Worth, upper and lower Woods Inlet, and Meandering Road Creek sites were the same penta- and hexa-chlorinated PCBs, indicating a close source linkage between sediment and the multiple trophic levels at each site. The detection of PCBs in zooplankton and fish from the Lake Worth site despite the fact PCBs were not detected in the surficial sediment at this site in previous USGS studies is likely the result of biomagnification of PCBs during predatorprey interactions with progressive accumulation of PCBs from lower trophic levels, represented by invertebrates, to higher trophic levels, represented by fish. Low PCB concentrations (less than the laboratory minimum reporting levels) might be present in surficial sediment at the Lake Worth site, facilitating biomagnification of PCBs near this site.

$\delta^{15} \mathrm{~N}$ generally increased as trophic level increased. An increase in the ratio of the heavier ${ }^{15} \mathrm{~N}$ isotope to the lighter ${ }^{14} \mathrm{~N}$ isotope in an organism, referred to as enrichment of ${ }^{15} \mathrm{~N}$ (denoted as $\delta^{15} \mathrm{~N}$ ), was highest in a biota sample from the highest trophic level sampled (largemouth bass, trophic level 4) and lowest in biota from the lowest trophic level sampled (true midge larvae, trophic level 2 ). $\delta^{15} \mathrm{~N}$ ranged from a maximum of $15.51 \%$ for largemouth bass from the Meandering Road Creek site to a minimum of $3.04 \%$ o for true midge larvae from the lower Woods Inlet site. Intermediate $\delta^{15} \mathrm{~N}$ values (between the $\delta^{15} \mathrm{~N}$ values measured in true midge larvae and largemouth bass samples) were measured in samples of longear sunfish, green sunfish, western mosquitofish, and gizzard shad (all trophic level 3). The highest $\delta^{15} \mathrm{~N}$ value measured in zooplankton (trophic level 2 or 3, depending on species composition) samples was $14.9 \%$, which was measured in a zooplankton sample from the upper Woods Inlet site.

Among biota samples, the range in $\delta^{15} \mathrm{~N}$ values was smaller for largemouth bass and the other fish taxa compared with the range in $\delta^{15} \mathrm{~N}$ values for the aquatic invertebrate taxa. For example, the range in $\delta^{15} \mathrm{~N}$ values measured in largemouth bass was $0.44 \%$ compared with $5.34 \%$ o for zooplankton.
Greater variation in $\delta^{15} \mathrm{~N}$ is expected in primary consumers, such as true midge larvae and zooplankton, compared with tertiary consumers, such as largemouth bass and other fish, because the invertebrates are shorter lived, and $\delta^{15} \mathrm{~N}$ in the invertebrates more closely reflects the temporal and spatial variability in the concentration of stable nitrogen isotopes in short-lived primary producers that they consume. Unlike stable ${ }^{15} \mathrm{~N}$, stable isotope ${ }^{13} \mathrm{C}$ is conserved through multiple trophic levels in an ecosystem. Increases in the ratio of the heavier ${ }^{13} \mathrm{C}$ isotope to the lighter ${ }^{12} \mathrm{C}$ isotope (referred to as $\delta^{13} \mathrm{C}$ ) were used to define the horizontal position of selected taxa to help determine if they were good candidates to use as primary consumers. The $\delta^{13} \mathrm{C}$ for true midge larvae collected in the Lake Worth and upper and lower Woods Inlet sites were more negative compared with the $\delta^{13} \mathrm{C}$ of other taxa, indicating true midge larvae were more depleted of ${ }^{13} \mathrm{C}$ compared with all other sampled aquatic invertebrate and fish. The relative depletion of ${ }^{13} \mathrm{C}$ in the true midge larvae might indicate this taxon obtains most of its carbon from dietary sources different from those of all other sampled invertebrates and fish. The $\delta^{13} \mathrm{C}$ for all other taxa were more positive compared with the $\delta^{13} \mathrm{C}$ for true midge larvae. The true midge larvae were collected in surficial sediment from 1 to 5 meters in depth, and as detritivores, the principal carbon source for this taxon might be phytoplankton detritus, benthic algae, or both. The majority of other invertebrate and fish taxa were collected in more shallow zones in the lake, inlet, and creek, generally less than 2 meters in depth, that were most likely dominated by carbon sourced from benthic-dwelling periphyton and benthic detritus.

Because the concentrations of bioaccumulating contaminants such as PCBs vary by trophic level, patterns of PCB concentrations in organisms representing different trophic levels with different amounts of nitrogen and carbon isotope enrichment can be used to make observations regarding patterns of bioaccumulation. At the Lake Worth and upper and lower Woods Inlet sites, the $\sum \mathrm{PCB}_{\mathrm{C} 15}$ concentration increases with nitrogen enrichment (as indicated by higher values $\delta^{15} \mathrm{~N}$ ) in accordance with trophic level, from aquatic invertebrates to fish, with the highest $\sum \mathrm{PCB}_{\mathrm{C} 15}$ concentrations and $\delta^{15} \mathrm{~N}$ values measured in largemouth bass.

Zooplankton (trophic level 2 or 3, depending on species composition) had relatively high $\delta^{15} \mathrm{~N}$ but low $\sum \mathrm{PCB}_{\mathrm{C} 15}$ concentrations compared with other invertebrate and vertebrate taxa. In zooplankton, the concentration of $\sum \mathrm{PCB}_{\mathrm{C} 15}$ was highest $(4.09 \mu \mathrm{g} / \mathrm{kg})$ at the upper Woods Inlet site where previous USGS studies indicated PCB concentrations in surficial sediment were highest. The number of zooplankton and associated sediment samples ( $\mathrm{n}=3$ for each) were insufficient to statistically evaluate the relation between the $\sum \mathrm{PCB}_{\mathrm{C} 15}$ concentration in zooplankton from the Lake Worth and Woods Inlet sites and the $\sum \mathrm{PCB}_{\mathrm{C} 15}$ concentration in surficial sediment measured at these sites in previous studies. Zooplankton feed on pelagicdwelling phytoplankton or other zooplankton and generally are not in physical contact with surficial sediment. The relatively high $\delta^{15} \mathrm{~N}$ but low $\sum \mathrm{PCB}_{\mathrm{C} 15}$ concentration in the zooplankton 
samples collected from the Lake Worth and Woods Inlet sites might indicate that zooplankton occupy multiple trophic levels. It also might indicate less bioavailability (degree to which a chemical can be taken up by biota) of PCBs from the water column where zooplankton feed compared with the bioavailability of PCBs from sediment where benthic organisms feed, or that PCB concentrations in pelagic food sources are lower compared with those in benthic food sources. A decrease in $\delta_{15} \mathrm{~N}$ in zooplankton samples collected from the upper Woods Inlet, lower Woods Inlet, and Lake Worth site (in that order) corresponds to a decrease in the percentage of predatory copepods present in each zooplankton sample from these sites. The large relative abundance of predatory copepods might explain the relatively high $\delta^{15} \mathrm{~N}$ for zooplankton compared with other taxa, whereas the lack of any trophic connection to surficial sediment would explain the relatively low $\sum \mathrm{PCB}_{\mathrm{C} 15}$ concentration for this taxon.

Whereas nitrogen enrichment as $\delta^{15} \mathrm{~N}$ in longear sunfish (trophic level 3) and largemouth bass (tropic level 4) is similar in magnitude, the $\sum \mathrm{PCB}_{\mathrm{Cl} 5}$ concentration is higher in largemouth bass and longear sunfish from the Woods Inlet sites (30.9 to $171.8 \mu \mathrm{g} / \mathrm{kg}$ ) compared with the $\sum \mathrm{PCB}_{\mathrm{C} 15}$ concentration in these fish collected from the Lake Worth site (3.48 to $28.8 \mu \mathrm{g} / \mathrm{kg}$ ). Because the invertebrate and fish communities at the Lake Worth and Woods Inlet sites are similar, the PCB concentrations measured in longear sunfish and largemouth bass and the biomagnification of PCBs at the higher trophic levels in the Lake Worth and Woods Inlet sites are likely controlled by differences in the PCB concentrations in surficial sediment.

$\delta^{15} \mathrm{~N}$ was more variable in aquatic invertebrates and fish collected from the Meandering Road Creek site compared with $\delta^{15} \mathrm{~N}$ values at the other sites. The $\delta^{15} \mathrm{~N}$ values measured in aquatic invertebrates and fish from the Meandering Road Creek site did not follow expected $\delta^{15} \mathrm{~N}$ levels for each taxon based on what is known about the diet and trophic level of the taxa. For example, $\delta^{15} \mathrm{~N}$ values measured in mayfly nymph samples were similar to those measured in longear sunfish and green sunfish, and the $\Sigma \mathrm{PCB}_{\mathrm{C} 15}$ measured in the mayfly nymph samples was about one-half the $\sum \mathrm{PCB}_{\mathrm{C} 15}$ measured in some fish (longear sunfish, western mosquitofish, and largemouth bass) from this site. This similarity in nitrogen enrichment among different trophic levels might be an indication of the open nature of stream ecosystems, compared with lakes, that contributes to larger variability in short- and long-term carbon and nitrogen sources.

Despite visual evidence of a monotonic association (positive correlation) between the $\Sigma \mathrm{PCB}_{\mathrm{C} 15}$ in biota and the $\sum \mathrm{PCB}_{\mathrm{C} 15}$ in surficial bed sediment, the small sample sizes $(\mathrm{n}=5$ for the Meandering Road Creek site, $\mathrm{n}=7$ for the Woods Inlet sites, and $\mathrm{n}=5$ for the Lake Worth site) likely contributed to the lack of statistically significant correlations between the $\delta^{15} \mathrm{~N}$ in biota and the $\sum \mathrm{PCB}_{\mathrm{C} 15}$ in surficial bed sediment (as evidenced by low rho values and high p-values). Stronger statistical correlations between $\delta^{15} \mathrm{~N}$ and the concentration of $\Sigma \mathrm{PCB}_{\mathrm{C} 15}$ in aquatic invertebrates and fish might be obtained by collecting and analyzing individual invertebrates and fish rather than the composite sample data that were obtained in this study, which greatly reduced the sample sizes available for statistical analyses.

\section{References}

Auster, P.J., Semmens, B.X., and Barber, Kimberly, 2005, Pattern in the co-occurrence of fishes inhabiting the coral reefs of Bonaire, Netherlands Antilles: Environmental Biology of Fishes, v. 74, p. 187-194.

Barnes, R.D., 1968, Invertebrate zoology: Philadelphia, Saunders, $743 \mathrm{p}$.

Bastviken, David, Ejlertsson, Jörgen, Sundh, Ingvar, and Tranvik, Lars, 2003, Methane as a source of carbon and energy for lake pelagic food webs: Ecology, v. 84, no. 4, p. 969-981.

Bayne, D.R., Reutebuch, E., and Seesock, W.C., 2002, Relative mobility of fishes in a southeastern reservoir based on tissue polychlorinated biphenyl residues: North American Journal of Fisheries Management, v. 22, p. 122-131.

Besse, R.E., Van Meter, P.C., and Wilson, J.T., 2005, Distribution and sources of polychlorinated biphenyls in Wood Inlet, Lake Worth, Fort Worth, Texas, 2003: U.S. Geological Survey Scientific Investigations Report 2005-2064, 46 p.

Borga, K., Fish, A.T., Hoekstra, P.F., and Muir, D.C.G., 2004, Biological and chemical factors of importance in the bioaccumulation and trophic transfer of persistent organochlorine contaminants in arctic marine food webs: Environmental Toxicology and Chemistry, v. 23, p. 2,367-2,385.

Braun, C.L., and Wilson, J.T., 2010, Polychlorinated biphenyls in suspended-sediment samples from outfalls to Meandering Road Creek at Air Force Plant 4, Fort Worth, Texas, 2003-08: U.S. Geological Survey Scientific Investigations Report 2010-5076, 20 p.

Braun, C.L., Wilson, J.T., and Van Metre, P.C., 2008, Degree of contamination and sources of polychlorinated biphenyls in Meandering Road Creek and Woods Inlet of Lake Worth, Fort Worth, Texas, 2004 and 2006-07: U.S. Geological Survey Scientific Investigations Report 2008-5177, 64 p.

Britton, L.J., and Greeson, P.E., eds., 1989, Methods for collection and analysis of aquatic biological and microbiological samples: U.S. Geological Survey, Techniques of WaterResources Investigations, book 5, chap. A4, 363 p.

Broman, D., Naf, C., Rolff, Y., Zebuhr, B., Fry, B., and Hobbie, J., 1992, Using ratios of stable nitrogen isotopes to estimate bioaccumulation and flux of polychlorinated dibenzo-p-dioxins (PCDDs) and dibenzofurans (PCDFs) in two food chains from the Northern Baltic: Environmental Toxicology and Chemistry, v. 11, p. 331-345. 
Burreau, S., Axelman, J., Broman, D., and Jakobson, E., 1997, Dietary uptake in pike (Esox lucius) of some polychlorinated biphenyls, polychlorinated naphthalenes and polybrominated diphenyl esters administered in natural diet: Environmental Toxicology and Chemistry, v. 16, p. 2,508-2,513.

Carbonell, G., Ramos, C., Pablos, M.V., Ortiz, J.A., and Tarazona, J.V., 2000, A system dynamic model for the assessment of different exposure routes in aquatic ecosystems: The Science of the Total Environment, v. 247, p. 107-118.

Childress, C.J.O., Foreman, W.T., Connor, B.F., and Maloney, T.J., 1999, New reporting procedures based on long-term method detection levels and some considerations for interpretations of water-quality data provided by the U.S. Geological Survey National Water Quality Laboratory: U.S. Geological Survey Open-File Report 99-193, 24 p.

City of Fort Worth, Texas, 2010, Water-Lake Worth: accessed June 7, 2010, at http://www.fortworthgov.org/ water/info/.

Clark, I.D., and Fritz, Peter, 1997, Environmental isotopes in hydrogeology: Boca Raton, Fla., CRC Press, 328 p.

Dietz, R., Riget, F., Cleemann, M., Aarkrog, A., Johansen, P., and Hansen, J.C., 2000, Comparison of contaminants from different trophic levels and ecosystems: The Science of the Total Environment, v. 245, p. 221-231.

Earth Tech, Inc., 2005, West side DNAPL and PCB investigation at Air Force Plant 4, Fort Worth, Texas: Prepared for U.S. Air Force, Aeronautical Systems Center, Environmental Management Directorate, Wright-Patterson Air Force Base, Ohio, Contract No. F41624-00-D-8023 [variously paged].

Erickson, M.D., 1997, Analytical chemistry of PCBs (2d ed.): Boca Raton, Fla., Lewis Publishers, 667 p.

Fowler, S.Q., Polikarpov, G.G., Elder, D.L., Parsi, P, and Villeneuve, J.P., 1978, Polychlorinated biphenyls-Accumulation from contaminated sediments and water by the polychaete Nereis diversicolor: Marine Biology, v. 48, p. 303-309.

Giggleman, C.M., and Lewis, J.M., 2004, Organochlorine pesticides and polychlorinated biphenyl contamination in rough and game fish collected from Lake Worth, Tarrant County, Texas, 2003: Arlington, Tex., U.S. Fish and Wildlife Service, Ecological Field Services Office, Region 2, project no. 1926-2507, 58 p., accessed July 21, 2010, at $h t t p: / / w w w$. fws.gov/southwest/es/arlingtontexas/pdf/LakeWorthReport. $p d f$.

Gobas, F.A.P.C., and Morrison, H.A., 2000, Bioconcentration and biomagnification in the aquatic environment-Chapter 9, in Boethling, R.S., and Mackay, Donald, eds., Handbook of property estimation methods for chemicals-Environmental and health sciences: Boca Raton, Fla., CRC Press, Part II, p. 189-232.

Harwell, G.R., Van Metre, P.C., Wilson, J.T., and Mahler, B.J., 2003, Spatial distribution and trends in trace elements, polycyclic aromatic hydrocarbons, organochlorine pesticides, and polychlorinated biphenyls in Lake Worth sediment, Fort Worth, Texas: U.S. Geological Survey Water-Resources Investigations Report 03-4269, 56 p.

Helm, P.A., Gewurtz, S.B., Whittle, D.M., Marvin, C.H., Fisk, A.T., and Tomy, G.T., 2008, Occurrence and biomagnifications of polychlorinated naphthalenes and non- and mono-ortho PCBs in Lake Ontario sediment and biota: Environmental Science and Technology, v. 42, no. 4, p. 1,024-1,031.

Helsel, D.R., and Hirsch, R.M., 2002, Statistical methods in water resources: U.S. Geological Survey Techniques of Water-Resources Investigations, book 4, chap. A3, 523 p., accessed May 29, 2010, at http://pubs.er.usgs.gov/pubs/twri/ twri04A3.

Hill, W.R., and Napolitano, G.E., 1997, PCB Congener accumulation by periphyton, herbivores, and omnivores: Archives of Environmental Contamination and Toxicology, v. 32 , p. 449-455.

Hogan, J.L., 2002, Fish, benthic-macroinvertebrate, and stream-habitat data from two estuaries near Galveston Bay, Texas, 2000-2001: U.S. Geological Survey Open-File Report 02-024, $16 \mathrm{p}$.

Hut, G., 1987, Consultant's group meeting on stable isotope reference samples for geochemical and hydrological investigations, September 16-18, 1985: Vienna, Report to Director General, International Atomic Energy Agency, 42 p.

International Commission on Zoological Nomenclature, 2010, Standards, sense, and stability for animal names in science: accessed October 5, 2010, at http://www.iczn.org.

Joaquim-Justo, C., Gosselain, V., and Descy, J.P., 1995, Relative importance of the trophic and direct pathways on PCB contamination in the rotifer species Brachionus calyciflorus (Pallas): Hydrobiologia, v. 314-315, no. 1, p. 249-257, accessed October 5, 2010, at http://www.springerlink.com/ content/k60t427202kh0541/.

Kendall, C., Silva, S.R., and Kelly, V.J., 2001, Carbon and nitrogen isotopic compositions of particulate organic matter in four large river systems across the United States: Hydrological Processes, v. 15, p. 1,301-1,346.

Kidd, K.A, 1998, Use of stable isotope ratios in freshwater and marine biomagnification studies, in Rose, J., ed., Environmental toxicology—Current development: New Delhi, India, Gordon and Breach Science, p. 357-376. 
Kidd, K.A, Bootsma, H.A., Hesslein, R.H., Muir, D.C.G., and Hecky, R.E., 2001, Biomagnification of DDT through the benthic and pelagic food webs of Lake Malawi, East Africa-Importance of trophic level and carbon source: Environmental Science and Technology, v. 35, p. 14-20.

Kling, G.W., Fry, B., and O’Brien, W.J., 1992, Stable isotopes and planktonic trophic structure in arctic lakes: Ecology, v. 73 , p. $561-566$.

Kohzu, Ayato, Tayasu, Ichiro, Yoshimizu, Chikage, Maruyama, Atsushi, Kohmatsu, Yukihiro, Hyodo, Fujio, Onoda, Yukio, Igeta, Akitake, Matsui, Kiyoshi, Nakano, Takanori, Wada, Eitaro, Nagata, Toshi, and Takemon, Yasuhiro, 2009, Nitrogen-stable isotopic signatures of basal food items, primary consumers and omnivores in rivers with different levels of human impact: Ecological Research, v. 24, no. 1, p. 127-136.

Larsson, P., 1984, Transport of PCBs from aquatic to terrestrial environments by emerging chironomids: Environmental Pollution Series A, Ecological and Biological, v. 34, p. 283-289.

Lehmann, E.L., and D'Abrera, H.J.M., 1998, Nonparametrics-Statistical methods based on ranks (rev. ed.): Englewood Cliffs, N.J., Prentice-Hall, p. 292-323.

Levine, Stephen, 1980, Several measures of trophic structure applicable to complex food webs: Journal of Theoretical Biology, v. 83, p. 195-207.

Lindqvist, Oliver, Johansson, Kjell, Aastrup, Mats, Andersson, Arne, Bringmark, Lage, Hovsenius, Gunnar, Hakanson, Lars, Iverfeldt, Ake, Meili, Markus, and Timm, Birgitta, 1991, Mercury in forest lake ecosystems-Bioavailability, bioaccumulation and biomagnifications, in Mercury in the Swedish environment-Recent research on causes, consequences and corrective methods: Water, Air and Soil Pollution, v. 55, p. 131-157.

Merritt, R.W., and Cummins, K.W., eds., 1996, An introduction to the aquatic insects of North America ( $3 \mathrm{~d}$ ed.): Dubuque, Iowa, Kendall and Hunt Publishing Co., 862 p.

Minagawa, Masao, and Wada, Eitaro, 1984, Stepwise enrichment of ${ }^{15} \mathrm{~N}$ along food chains-Further evidence and the relation between $\delta^{15} \mathrm{~N}$ and animal age: Geochimica et Cosmochimica Acta, v. 48, no. 5, p. 1,135-1,140.

Moring, J.B., 2002, Data on occurrence of selected trace metals, organochlorines, and semivolatile organic compounds in edible fish tissues from Lake Worth, Texas, 1999: U.S. Geological Survey Open-File Report 02-016, 23 p.

Moulton, S.R., Kennen, J.G., Goldstein, R.M., and Hambrook, J.A., 2002, Revised protocols for sampling algal, invertebrate, and fish communities as part of the National WaterQuality Assessment Program: U.S. Geological Survey
Open-File Report 02-150, 75 p., accessed July 1, 2010, at http://pubs.usgs.gov/of/2002/ofr-02-150/pdf/ofr02-150.pdf.

Nielsen, L.A., and Johnson, D.L., 1983, Fisheries techniques: Bethesda, Md., American Fisheries Society Publication, $468 \mathrm{p}$.

Omernick, J.N., 1987, Ecoregions of the conterminous United States: Annals of the Association of American Geographers, v. 77 , p. $118-125$.

Ott, R.L., 1993, An introduction to statistical methods and data analysis (4th ed.): Belmont, Calif., Duxbury Press, 1,051 p.

Pennak, R.W., 1989, Fresh-water invertebrates of the United States (3d ed.): New York, John Wiley, 628 p.

Paulson, A.J., Konrad, C.P., Frans, L.M., Noble, M., Kendall, C., Josberger, E.G., Huffman, R.L., and Olsen, T.D., 2006, Freshwater and saline loads of dissolved inorganic nitrogen to Hood Canal and Lynch Cove, western Washington: U.S. Geological Survey Scientific Investigations Report 20065106, 92 p., accessed June 23, 2010, at http://pubs.usgs.gov/ sir/2006/5106/pdf/sir20065106.pdf.

Peterson, B.J., and Fry, B., 1987, Stable isotopes in ecosystem studies: Annual Review of Ecological Systematics, v. 18, p. 293-320.

Post, D.M., 2002, Using stable isotopes to estimate trophic position-Models, methods, and assumptions: Ecology, v. 83, p. $703-718$.

Preisser, E.L., 2008, Trophic structure, in Jorgensen, S.E., and Fath, B.D., eds., Encyclopedia of ecology: Oxford, Elsevier Press, p. 3,608-3,616.

Rand, C.M., and Petrocelli, S.R., 1985, Fundamentals of aquatic toxicology: New York, Harper and Row, 666 p.

Resh, V.H., and Rosenberg, D.M., 1984, The ecology of aquatic insects: New York, Praeger, 625 p.

Ricklefs, R.E., 1979, Ecology (2d ed.): New York, Chiron Press, $966 \mathrm{p}$.

Rognerud, S., Grimalt, J.O., Rosseland, B.O., Fernández, P., Hofer, R., Lackner, R., Lauritzen, B., Lien, L., Massabuau, J.C., and Ribes, A., 2002, Mercury and organochlorine contamination in brown trout (Salmo trutta) and Arctic charr (Salvelinus alpinus) from high mountain lakes in Europe and the Svalbard archipelago: Water, Air, and Soil Pollution, Focus 2, p. 209-232, accessed March 10, 2010, at $h t t p: / / w w w . s p r i n g e r l i n k . c o m / c o n t e n t / u 7 p 21562432$ th073/ fulltext.pdf.

Rolff, C., Broman, D., Naf, C., and Zebuhr, Y., 1993, Potential biomagnification of PCDD/Fs-New possibilities for quantitative assessment using stable isotope trophic position: Chemosphere, v. 27, p. 461-468. 
Ruddy, B.C., and Hitt, K.J., 1990, Summary of selected characteristics of large reservoirs in the United States and Puerto Rico, 1988: U.S. Geological Survey Open-File Report 90-163, 295 p.

Russ, A., Ugland, K.I., and Skaare, J.U., 2002, Influence of trophic position on organochlorine concentrations and compositional patterns in a marine food web: Environmental Toxicology and Chemistry, v. 21, p. 2,356-2,364.

Russell, R.W., Gobas, F.A.P.C., and Haffner, G.D., 1999, Role of chemical and ecological factors in trophic transfer of organic chemicals in aquatic food webs: Environmental Toxicology and Chemistry, v. 18, p. 1,250-1,257.

Sprules, W.G., and Bowerman J.E., 1988, Omnivory and food chain length in zooplankton food webs: Ecology, v. 69, no. 2 , p. 418-426.

StatSoft, 2006, Statistica for Windows and Windows XP Professional (version 7): Tulsa, Okla., Statsoft, Inc.

Steele, K.W., and Daniel, R.M., 1978, Fractionation of nitrogen isotopes by animals-A further complication to the use of variations in natural abundance of ${ }^{15} \mathrm{~N}$ for tracer studies: Journal of Agricultural Science, v. 90, p. 7-9.

Texas Commission on Environmental Quality, 2005, One total maximum daily load for polychlorinated biphenyls (PCBs) in fish tissues in Lake Worth for segment 0807: Chief Engineer's Office, Water Programs, TMDL Section, 51 p., accessed June 18, 2010, at http://www.epa.gov/waters/ tmdldocs/12373_LakeWorthEPAPackage.pdf.

Texas Department of Health, 1998, Public health assessment, U.S. Air Force Plant No. 4 (Lockheed Martin), Fort Worth, Tarrant County, Texas: Comprehensive Environmental Response, Compensation, and Liability Information System, CERCLIS no. TX75720246045, 39 p.

Texas Department of State Health Services, 2000, Fish and shellfish consumption advisory ADV-18 (Lake Worth, April 19, 2000): accessed February 9, 2010, at http://www.dshs. state.tx.us/seafood/PDF2/Active/ADV-18_signed_WorthL. $p d f$.
Texas Department of State Health Services, 2007, Standard operating procedures and quality control/assurance manual: Seafood and Aquatic Life Group Survey Team, 98 p.

Thomas, Chad, Bonner, T.H., and Whiteside, B.G., 2007, Freshwater fishes of Texas-A field guide: College Station, Tex., Texas A\&M University Press, 220 p.

U.S. Environmental Protection Agency, 2008, Aroclor and other PCB mixtures: accessed December 14, 2009, at http://www.epa.gov/wastes/hazard/tsd/pcbs/pubs/aroclor. htm.

U.S. Geological Survey, 2004, Resources on isotopes-Fundamentals of stable isotope geochemistry: accessed April 10, 2009, at http://wwwrcamnl.wr.usgs.gov/isoig/res/funda.html.

U.S. Geological Survey, 2010, National Water Information System-USGS water data for Texas: accessed July 2010 at http://waterdata.usgs.gov/tx/nwis/.

Vander Zanden, M.J., and Fetzer, W.W., 2007, Global patterns of aquatic food chain length: Oikos, v. 116, p. 1,378-1,388, accessed June 4, 2010, at http://bsu.edu/web/mpyron/ Bio480/GlobalFoodChainLength.pdf.

Vander Zanden, M.J., and Rasmussen, J.B., 1999, Primary consumer $\delta^{13} \mathrm{C}$ and $\delta^{15} \mathrm{~N}$ and the trophic position of aquatic consumers: Ecology, v. 80, p. 1,395-1,404.

Vander Zanden, M.J., and Rasmussen, J.B., 2001, Variation in $\delta^{15} \mathrm{~N}$ and $\delta^{13} \mathrm{C}$ trophic fractionation-Implications for aquatic food web studies: Limnology and Oceanography, v. 46 , no. 8 , p. $2,061-2,066$.

Williamson, C.E., and Reid, J.W., 2001, Copepoda-Chapter 22, in Thorp, J.H., and Covich, A.P., eds., Ecology and classification of North American freshwater invertebrates: San Diego, Calif., Academic Press, p. 915-953.

Wojtal, A., Frankiewicz, P., Izydorczyk, K., and Zalewski, M., 2003, Horizontal migration of zooplankton in a littoral zone of the lowland Sulejow Reservoir (Central Poland): Hydrobiologia, v. 506-509, p. 339-346. 
Blank Page 
Appendixes 1-3 
Appendix 1. Relative percent difference for duplicate polychlorinated biphenyl congener and isotope data for aquatic invertebrate and fish samples collected in Lake Worth, Woods Inlet, and Meandering Road Creek, Fort Worth, Texas, 2007-08.

[LW, Lake Worth; RPD, relative percent difference; WI, Woods Inlet; MC, Meandering Road Creek; PCB, polychlorinated biphenyl; $\mu \mathrm{g} / \mathrm{kg}$, micrograms per kilogram; --, not analyzed for; \%o, per mil; $\delta^{15} \mathrm{~N}$, delta nitrogen- $15 ; \delta^{13} \mathrm{C}$, delta carbon-13]

\begin{tabular}{|c|c|c|c|c|c|c|c|c|c|}
\hline & \multirow{2}{*}{\multicolumn{3}{|c|}{$\begin{array}{c}\text { Lake Worth near State } \\
\text { Highway } 199 \text { Bridge } \\
\text { (004LW) }\end{array}$}} & \multicolumn{3}{|c|}{$\begin{array}{l}\text { Lake Worth in upper Woods Inlet } \\
\qquad(002 \mathrm{WI})\end{array}$} & \multicolumn{3}{|c|}{$\begin{array}{l}\text { Meandering Road Creek near } \\
\text { confluence with Lake Worth } \\
\text { (001MC) }\end{array}$} \\
\hline & & & & Gre & en sunfish & & \multicolumn{3}{|c|}{ Dragonfly nypmhs } \\
\hline & $\begin{array}{l}\text { Original } \\
\text { environmental } \\
\text { sample }\end{array}$ & $\begin{array}{l}\text { Duplicate } \\
\text { sample }\end{array}$ & RPD & $\begin{array}{c}\text { Original } \\
\text { environmental } \\
\text { sample }\end{array}$ & $\begin{array}{l}\text { Duplicate } \\
\text { sample }\end{array}$ & RPD & $\begin{array}{c}\text { Original } \\
\text { environmental } \\
\text { sample }\end{array}$ & $\begin{array}{l}\text { Duplicate } \\
\text { sample }\end{array}$ & RPD \\
\hline PCB 101 & -- & -- & -- & 26.30 & 16.55 & 45.51 & -- & -- & -- \\
\hline PCB 110 & -- & -- & -- & 23.20 & 16.04 & 36.52 & -- & -- & -- \\
\hline PCB 118 & -- & -- & -- & 6.94 & 5.91 & 16.05 & -- & -- & -- \\
\hline PCB 138 & -- & -- & -- & 15.80 & 13.21 & 17.89 & -- & -- & -- \\
\hline PCB 170 & -- & -- & -- & 6.59 & 5.30 & 21.68 & -- & -- & -- \\
\hline PCB 174 & -- & -- & -- & 3.91 & 3.21 & 19.63 & -- & -- & -- \\
\hline PCB 177 & -- & -- & -- & 2.04 & 1.73 & 16.50 & -- & -- & -- \\
\hline PCB 180 & -- & -- & -- & 11.90 & 9.12 & 26.45 & -- & -- & -- \\
\hline PCB 183 & -- & -- & -- & 2.68 & 2.11 & 23.85 & -- & -- & -- \\
\hline PCB 187 & -- & -- & -- & 6.21 & 4.96 & 22.40 & -- & -- & -- \\
\hline РCB 194 & -- & -- & -- & 2.79 & 1.96 & 35.10 & -- & -- & -- \\
\hline PCB 206 & -- & -- & -- & 1.37 & .86 & 45.25 & -- & -- & -- \\
\hline
\end{tabular}


Appendix 2. Laboratory sample blank and spike percent recovery for polychlorinated biphenyl congeners and surrogate compounds for two sets analyzed concurrently with aquatic invertebrate and fish samples collected in Lake Worth, Woods Inlet, and Meandering Road Creek, Fort Worth, Texas, 2007-08.

[PCB, polychlorinated biphenyl; ND, nondetection less than method detection limit; DDT- $d 8,1,1^{\prime}$-bis( $p$-chlorophenyl)-2,2,2-trichloroethane; PCB 202-13C12, 2,2',3,3',5,5',6,6'-octachlorobiphenyl]

\begin{tabular}{|c|c|c|c|c|}
\hline & \multicolumn{2}{|c|}{ Sample blank percent recovery } & \multicolumn{2}{|c|}{ Environmental sample spike percent recovery } \\
\hline & Set 1 & Set 2 & Set 1 & Set 2 \\
\hline \multicolumn{5}{|c|}{ PCB congener } \\
\hline PCB101 & ND & ND & 75.60 & 138.00 \\
\hline PCB110 & ND & ND & 92.40 & 150.00 \\
\hline PCB151 & ND & ND & 66.70 & 58.10 \\
\hline PCB149 & ND & ND & 70.30 & 64.40 \\
\hline PCB118 & ND & ND & 61.20 & 67.80 \\
\hline PCB146 & ND & ND & 61.70 & 70.80 \\
\hline PCB138 & ND & ND & 71.80 & 71.20 \\
\hline PCB187 & ND & ND & 62.40 & 64.00 \\
\hline PCB183 & ND & ND & 59.50 & 61.00 \\
\hline PCB174 & ND & ND & 64.30 & 64.40 \\
\hline PCB177 & ND & ND & 59.00 & 62.70 \\
\hline PCB180 & ND & ND & 58.20 & 63.40 \\
\hline PCB170 & ND & ND & 47.00 & 63.50 \\
\hline PCB194 & ND & ND & 58.00 & 63.30 \\
\hline PCB206 & ND & ND & 59.10 & 62.50 \\
\hline \multicolumn{5}{|c|}{ Surrogate compound } \\
\hline DDT- $d 8$ & 56.10 & 59.60 & 55.20 & 58.80 \\
\hline PCB 202-13C12 & 68.20 & 76.20 & 73.80 & 76.20 \\
\hline
\end{tabular}


Appendix 3. Concentrations of selected polychlorinated biphenyl congeners and number of chlorinated substitutes for aquatic invertebrate and fish composite samples collected in Lake Worth, Woods Inlet, and Meandering Road Creek, Fort Worth, Texas, 2007-08.

[Concentrations in micrograms per kilogram $(\mu \mathrm{g} / \mathrm{kg})$ wet weight; PCB, polychlorinated biphenyl; LW, Lake Worth; <, less than laboratory method detection limit; ---, no data; E, estimated value less than laboratory minimum reporting level; WI, Woods Inlet; MC, Meandering Creek]

\begin{tabular}{|c|c|c|c|c|c|c|c|c|c|c|c|c|c|}
\hline \multirow[b]{2}{*}{$\begin{array}{l}\text { Site } \\
\text { descrip- } \\
\text { tion }\end{array}$} & \multirow{2}{*}{$\begin{array}{c}\text { Site } \\
\text { identi- } \\
\text { fier } \\
\text { (fig. 1) }\end{array}$} & \multirow{2}{*}{$\begin{array}{c}\text { Method } \\
\text { detection } \\
\text { limit } \\
(\mu \mathrm{g} / \mathrm{kg})\end{array}$} & \multirow{2}{*}{$\begin{array}{l}\text { PCB } \\
\text { con- } \\
\text { gener }\end{array}$} & \multirow{2}{*}{$\begin{array}{l}\text { Chlori- } \\
\text { nated } \\
\text { substi- } \\
\text { tute }\end{array}$} & \multicolumn{4}{|c|}{ Aquatic invertebrates } & \multicolumn{5}{|c|}{ Fish } \\
\hline & & & & & $\begin{array}{l}\text { Midge } \\
\text { larvae }\end{array}$ & $\begin{array}{l}\text { Zoo- } \\
\text { plank- } \\
\text { ton }\end{array}$ & $\begin{array}{l}\text { Mayfly } \\
\text { nymphs }\end{array}$ & $\begin{array}{c}\text { Dragonfly } \\
\text { nymphs }\end{array}$ & $\begin{array}{c}\text { Large- } \\
\text { mouth } \\
\text { bass }\end{array}$ & $\begin{array}{c}\text { Green } \\
\text { sunfish }\end{array}$ & $\begin{array}{l}\text { Longear } \\
\text { sunfish }\end{array}$ & $\begin{array}{l}\text { Western } \\
\text { mosquito- } \\
\text { fish }\end{array}$ & $\begin{array}{c}\text { Gizzard } \\
\text { shad }\end{array}$ \\
\hline \multirow{15}{*}{$\begin{array}{l}\text { Lake } \\
\text { Worth } \\
\text { near } \\
\text { State } \\
\text { High- } \\
\text { way } 199 \\
\text { Bridge }\end{array}$} & \multirow[t]{15}{*}{$004 \mathrm{LW}$} & 4.0 & 101 & Penta- & $<4$ & $<4$ & --- & --- & 4.44 & --- & $<4$ & --- & $<4$ \\
\hline & & 10.0 & 110 & Penta- & $<10$ & $<10$ & --- & --- & E7.9 & --- & $<10$ & --- & $<10$ \\
\hline & & .4 & 118 & Penta- & $<.4$ & E. 14 & --- & --- & 1.69 & --- & E.27 & --- & E.64 \\
\hline & & .2 & 138 & Hexa- & $<.2$ & .84 & --- & --- & 1.25 & --- & .59 & --- & E1.17 \\
\hline & & .2 & 146 & Hexa- & $<.2$ & E.12 & --- & --- & .72 & --- & .58 & --- & E. 3 \\
\hline & & 2.0 & 149 & Hexa- & $<2$ & E.03 & --- & --- & E1.25 & --- & $<2$ & --- & E1.17 \\
\hline & & .2 & 151 & Hexa- & $<.2$ & E.1 & --- & --- & E. 86 & --- & E.03 & --- & E1.25 \\
\hline & & .2 & 170 & Hepta- & $<.2$ & $<.2$ & --- & --- & .81 & --- & $<.2$ & --- & E.09 \\
\hline & & .2 & 174 & Hepta- & $<.2$ & $<.2$ & --- & --- & E. 45 & --- & E.02 & --- & E. 54 \\
\hline & & .2 & 177 & Hepta- & $<.2$ & $<.2$ & --- & --- & .28 & --- & .93 & --- & E. 2 \\
\hline & & .2 & 180 & Hepta- & $<.2$ & E.02 & --- & --- & 1.74 & --- & .48 & --- & E.17 \\
\hline & & .4 & 183 & Hepta- & $<.4$ & E.04 & --- & --- & E.27 & --- & E.29 & --- & E. 29 \\
\hline & & .2 & 187 & Hepta- & $<.2$ & E.01 & --- & --- & 1.93 & --- & .28 & --- & .54 \\
\hline & & .4 & 194 & Octa- & $<.4$ & E.06 & --- & --- & E.14 & --- & $<.4$ & --- & E. 23 \\
\hline & & .2 & 206 & Nona- & $<.2$ & $<.2$ & --- & --- & $<.2$ & --- & $<.2$ & --- & .33 \\
\hline
\end{tabular}

\begin{tabular}{|c|c|c|c|c|c|c|c|c|c|c|c|c|c|}
\hline \multirow[b]{2}{*}{$\begin{array}{c}\text { Site } \\
\text { description }\end{array}$} & \multirow{2}{*}{$\begin{array}{c}\text { Site } \\
\text { identi- } \\
\text { fier } \\
\text { (fig. 1) }\end{array}$} & \multirow{2}{*}{$\begin{array}{c}\text { Method } \\
\text { detec- } \\
\text { tion } \\
\text { limit } \\
(\mu \mathrm{g} / \mathrm{kg})\end{array}$} & \multirow[b]{2}{*}{$\begin{array}{l}\text { PCB } \\
\text { con- } \\
\text { gener }\end{array}$} & \multirow{2}{*}{$\begin{array}{l}\text { Chlori- } \\
\text { nated } \\
\text { substi- } \\
\text { tute }\end{array}$} & \multicolumn{4}{|c|}{ Aquatic invertebrates } & \multicolumn{5}{|c|}{ Fish } \\
\hline & & & & & $\begin{array}{l}\text { Midge } \\
\text { larvae }\end{array}$ & $\begin{array}{l}\text { Zoo- } \\
\text { plank- } \\
\text { ton }\end{array}$ & $\begin{array}{l}\text { Mayfly } \\
\text { nymphs }\end{array}$ & $\begin{array}{c}\text { Dragonfly } \\
\text { nymphs }\end{array}$ & $\begin{array}{c}\text { Large- } \\
\text { mouth } \\
\text { bass }\end{array}$ & $\begin{array}{l}\text { Green } \\
\text { sunfish }\end{array}$ & $\begin{array}{l}\text { Longear } \\
\text { sunfish }\end{array}$ & $\begin{array}{l}\text { Western } \\
\text { mosquito- } \\
\text { fish }\end{array}$ & $\begin{array}{l}\text { Gizzard } \\
\text { shad }\end{array}$ \\
\hline \multirow{15}{*}{$\begin{array}{l}\text { Lake Worth } \\
\text { in lower } \\
\text { Woods } \\
\text { Inlet }\end{array}$} & 003WI & 4.0 & 101 & Penta- & E3.2 & $<4$ & --- & --- & 7.4 & --- & 4.66 & --- & --- \\
\hline & & 10.0 & 110 & Penta- & E2.5 & E.14 & --- & --- & E7.78 & --- & E1.27 & --- & --- \\
\hline & & .4 & 118 & Penta- & .93 & E.21 & --- & --- & 5.05 & --- & 2.67 & --- & --- \\
\hline & & .2 & 138 & Hexa- & 2.12 & .37 & --- & --- & 16.5 & --- & 4.42 & --- & --- \\
\hline & & .2 & 146 & Hexa- & .27 & .20 & --- & --- & 3.02 & --- & 1.4 & --- & --- \\
\hline & & 2.0 & 149 & Hexa- & 2.71 & E. 05 & --- & --- & 11.2 & --- & 3.82 & --- & --- \\
\hline & & .2 & 151 & Hexa- & .38 & .20 & --- & --- & 2.1 & --- & .76 & --- & --- \\
\hline & & .2 & 170 & Hepta- & .49 & E.04 & --- & --- & 5.24 & --- & 2.14 & --- & --- \\
\hline & & .2 & 174 & Hepta- & .46 & E.05 & --- & --- & 2.21 & --- & .64 & --- & --- \\
\hline & & .2 & 177 & Hepta- & E.18 & $<.2$ & --- & --- & 1.37 & --- & .58 & --- & --- \\
\hline & & .2 & 180 & Hepta- & .62 & .02 & --- & --- & 8.92 & --- & 4.14 & --- & --- \\
\hline & & .4 & 183 & Hepta- & E. 20 & E.09 & --- & --- & 2.36 & --- & .89 & --- & --- \\
\hline & & .2 & 187 & Hepta- & .65 & E.02 & --- & --- & 5.95 & --- & 2.49 & --- & --- \\
\hline & & .4 & 194 & Octa- & E.16 & E.08 & --- & --- & 2.52 & --- & .69 & --- & --- \\
\hline & & .2 & 206 & Nona- & E.01 & $<.2$ & --- & --- & 1.04 & --- & .33 & --- & --- \\
\hline
\end{tabular}


Appendix 3. Concentrations of selected polychlorinated biphenyl congeners and number of chlorinated substitutes for aquatic invertebrate and fish composite samples collected in Lake Worth, Woods Inlet, and Meandering Road Creek, Fort Worth, Texas, 2007-08-Continued.

\begin{tabular}{|c|c|c|c|c|c|c|c|c|c|c|c|c|c|}
\hline $\begin{array}{l}\text { Site de- } \\
\text { scription }\end{array}$ & $\begin{array}{c}\text { Site } \\
\text { identi- } \\
\text { fier } \\
\text { (fig. 1) }\end{array}$ & $\begin{array}{l}\text { Method } \\
\text { detec- } \\
\text { tion } \\
\text { limit } \\
(\mu \mathrm{g} / \mathrm{kg})\end{array}$ & $\begin{array}{l}\text { PCB } \\
\text { con- } \\
\text { gener }\end{array}$ & $\begin{array}{l}\text { Chlori- } \\
\text { nated } \\
\text { substi- } \\
\text { tute }\end{array}$ & \multicolumn{4}{|c|}{ Aquatic invertebrates } & \multicolumn{5}{|c|}{ Fish } \\
\hline \multirow{11}{*}{$\begin{array}{l}\text { Lake Worth } \\
\text { in upper } \\
\text { Woods } \\
\text { Inlet }\end{array}$} & 002WI & 4.0 & 101 & Penta- & 10.1 & E0.50 & --- & --- & 35.7 & --- & 22.3 & --- & 20.07 \\
\hline & & 10.0 & 110 & Penta- & 10.4 & E.77 & --- & --- & 23.5 & --- & E7.89 & --- & 19.62 \\
\hline & & .2 & 138 & Hexa- & 7.14 & .70 & --- & --- & 15.8 & --- & 22.0 & --- & 14.5 \\
\hline & & .2 & 146 & Hexa- & 1.24 & E.12 & --- & --- & 6.01 & --- & 3.38 & --- & 3.12 \\
\hline & & 2.0 & 149 & Hexa- & 9.42 & .59 & --- & --- & 27.9 & --- & 17.0 & --- & 21.75 \\
\hline & & .2 & 151 & Hexa- & 1.16 & E.11 & --- & --- & 4.43 & --- & 3.95 & --- & 3.28 \\
\hline & & .2 & 180 & Hepta- & 3.83 & .24 & --- & --- & 16.2 & --- & 8.82 & --- & 10.51 \\
\hline & & .4 & 183 & Hepta- & .77 & E.07 & --- & --- & 4.5 & --- & 2.98 & --- & 2.39 \\
\hline & & .2 & 187 & Hepta- & 1.9 & E.14 & --- & --- & 11.2 & --- & 8.14 & --- & 5.58 \\
\hline & & .4 & 194 & Octa- & .70 & E.04 & --- & --- & 3.58 & --- & 2.5 & --- & 2.37 \\
\hline & & .2 & 206 & Nona- & .25 & .20 & --- & --- & 1.22 & --- & 1.12 & --- & 1.12 \\
\hline
\end{tabular}

\begin{tabular}{|c|c|c|c|c|c|c|c|c|c|c|c|c|c|}
\hline \multirow[b]{2}{*}{$\begin{array}{c}\text { Site } \\
\text { description }\end{array}$} & \multirow[b]{2}{*}{$\begin{array}{c}\text { Site } \\
\text { identi- } \\
\text { fier } \\
\text { (fig. 1) }\end{array}$} & \multirow{2}{*}{$\begin{array}{c}\text { Method } \\
\text { detec- } \\
\text { tion } \\
\text { limit } \\
(\mu \mathrm{g} / \mathrm{kg})\end{array}$} & \multirow[b]{2}{*}{$\begin{array}{l}\text { PCB } \\
\text { con- } \\
\text { gener }\end{array}$} & \multirow[b]{2}{*}{$\begin{array}{l}\text { Chlori- } \\
\text { nated } \\
\text { substi- } \\
\text { tute }\end{array}$} & \multicolumn{4}{|c|}{ Aquatic invertebrates } & \multicolumn{5}{|c|}{ Fish } \\
\hline & & & & & $\begin{array}{l}\text { Midge } \\
\text { larvae }\end{array}$ & $\begin{array}{c}\text { Zoo- } \\
\text { plank- } \\
\text { ton }\end{array}$ & $\begin{array}{l}\text { Mayfly } \\
\text { nymphs }\end{array}$ & $\begin{array}{c}\text { Dragonfly } \\
\text { nymphs }\end{array}$ & $\begin{array}{c}\text { Large- } \\
\text { mouth } \\
\text { bass }\end{array}$ & $\begin{array}{c}\text { Green } \\
\text { sunfish }\end{array}$ & $\begin{array}{c}\text { Longear } \\
\text { sunfish }\end{array}$ & $\begin{array}{l}\text { Western } \\
\text { mosquito- } \\
\text { fish }\end{array}$ & $\begin{array}{l}\text { Gizzard } \\
\text { shad }\end{array}$ \\
\hline \multirow{12}{*}{$\begin{array}{l}\text { Meander- } \\
\text { ing Road } \\
\text { Creek } \\
\text { near } \\
\text { conflu- } \\
\text { ence } \\
\text { with } \\
\text { Lake } \\
\text { Worth }\end{array}$} & \multirow{12}{*}{ 001MC } & 4.0 & 101 & Penta- & --- & --- & 5.04 & $<4$ & 14.4 & $<4$ & 16.0 & 17.9 & --- \\
\hline & & 10.0 & 110 & Penta- & --- & --- & E6.38 & $<10$ & 15.7 & $<10$ & 17.1 & 20.6 & --- \\
\hline & & .2 & 138 & Hexa- & --- & --- & 6.83 & $<.2$ & 11.5 & .03 & 11.8 & 8.55 & --- \\
\hline & & .2 & 146 & Hexa- & --- & --- & .70 & E.14 & 2.4 & E.05 & 2.95 & 2.36 & --- \\
\hline & & 2.0 & 149 & Hexa- & --- & --- & 5.34 & $<2$ & 13.2 & $<2$ & 18.6 & 14.2 & --- \\
\hline & & .2 & 151 & Hexa- & --- & --- & .54 & .30 & 1.02 & $<.2$ & 2.85 & 1.49 & --- \\
\hline & & .2 & 177 & Hepta- & --- & --- & .25 & $<.2$ & .57 & .23 & 1.43 & .96 & --- \\
\hline & & .2 & 180 & Hepta- & --- & --- & 2.24 & .35 & 6.88 & E.09 & 7.35 & 5.48 & --- \\
\hline & & .4 & 183 & Hepta- & --- & --- & .36 & $<.2$ & 1.16 & E.02 & 1.36 & .95 & --- \\
\hline & & .2 & 187 & Hepta- & --- & --- & .88 & .39 & 3.33 & E.01 & 6.77 & 3.27 & --- \\
\hline & & .4 & 194 & Octa- & --- & --- & E.17 & E. 28 & .89 & $<.4$ & 1.06 & E.02 & --- \\
\hline & & .2 & 206 & Nona- & --- & --- & $<.2$ & E.18 & .36 & $<.2$ & .51 & $<.2$ & --- \\
\hline
\end{tabular}


Publishing support provided by Lafayette Publishing Service Center

Information regarding water resources in Texas is available at http://tx.usgs.gov/ 
Blank Page 


\section{$\frac{2}{2}$}
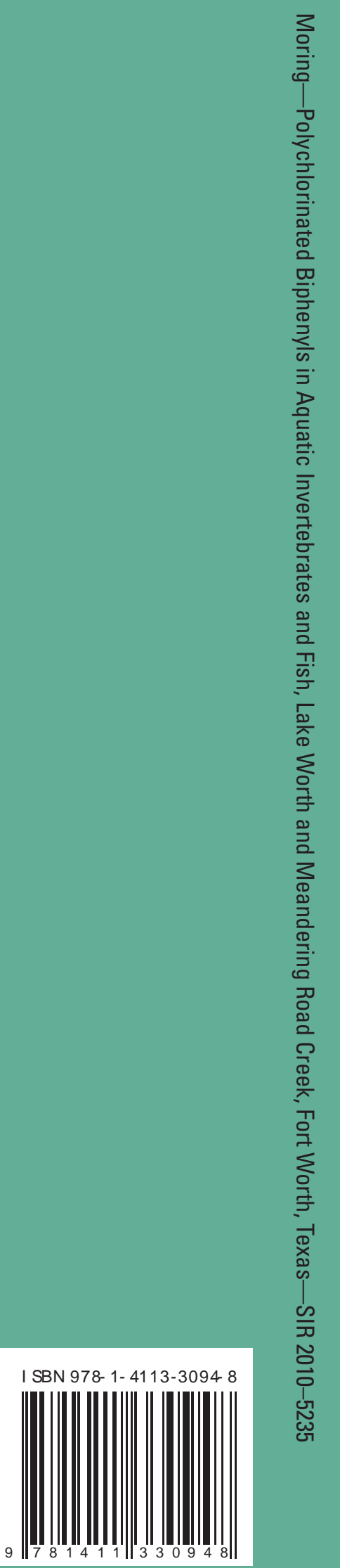